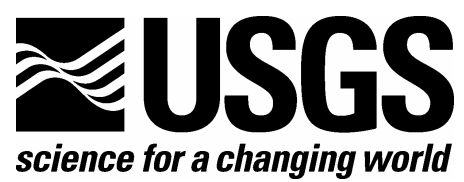

Prepared in cooperation with the Bureau of Land Management

\title{
Geophysical Framework Investigations Influencing Ground-water Resources in East-central Nevada and West-central Utah
}

By Janet T. Watt and David A. Ponce

With a section on

\section{Geologic and Geophysical Basin-by-basin Descriptions}

By Alan R. Wallace, Janet T. Watt, and David A. Ponce

Open-File Report 2007-1163

U.S. Department of the Interior

U.S. Geological Survey 


\title{
U.S. Department of the Interior DIRK KEMPTHORNE, Secretary
}

\author{
U.S. Geological Survey \\ Mark D. Myers, Director
}

U.S. Geological Survey, Reston, Virginia 2007

For product and ordering information:

World Wide Web: http://www.usgs.gov/pubprod

Telephone: 1-888-ASK-USGS

For more information on the USGS - the Federal source for science about the Earth, its natural and living resources, natural hazards, and the environment:

World Wide Web: http://www.usgs.gov

Telephone: 1-888-ASK-USGS

Suggested citation:

Watt, Janet T., and Ponce, David A., 2007, Geophysical framework investigations influencing ground-water resources in east-central Nevada and west-central Utah, with a section on Geologic and geophysical basin-by-basin descriptions by Wallace, Alan R., Watt, Janet T., and Ponce David A.: U.S. Geological Survey Open-File Report 2007-1163

[http://pubs.usgs.gov/of/2007/1163].

Any use of trade, product, or firm names is for descriptive purposes only and does not imply endorsement by the U.S. Government.

Although this report is in the public domain, permission must be secured from the individual copyright owners to reproduce any copyrighted material contained within this report. 


\section{Contents}

Abstract

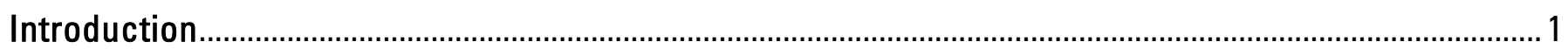

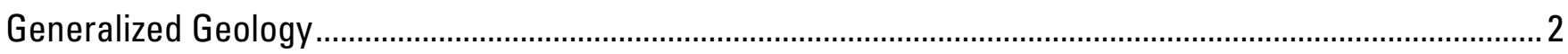

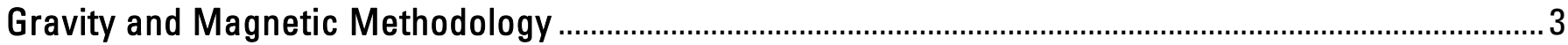

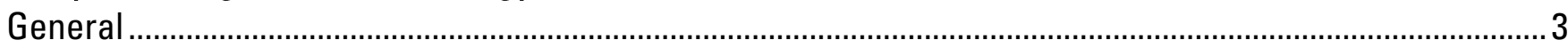

Gravity Inversion - Depth to Basement ................................................................................................ 4

Boundary Analysis of Gravity and Magnetic Sources..............................................................................

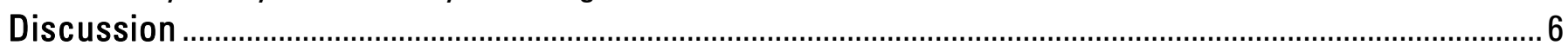

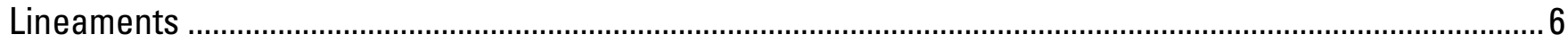

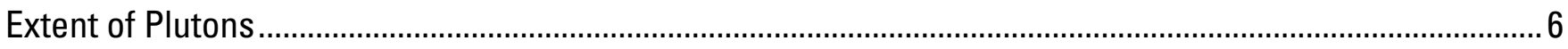

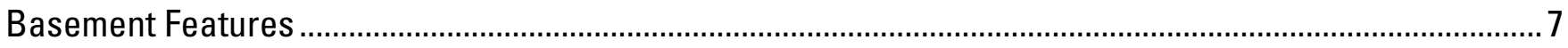

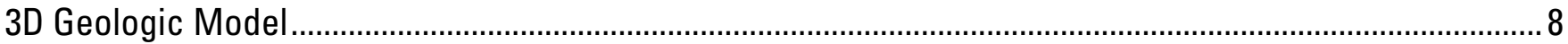

Geologic and Geophysical Basin-by-basin Descriptions .....................................................................

Basin stratigraphy and tectonics ...................................................................................................

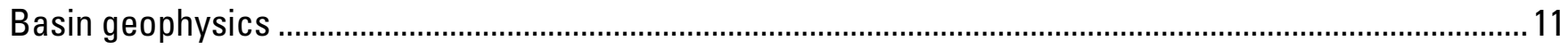

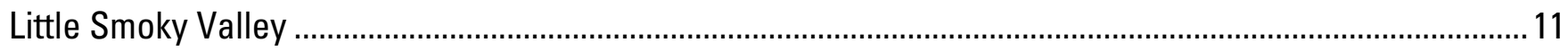

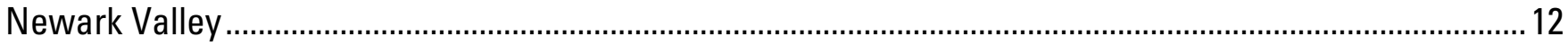

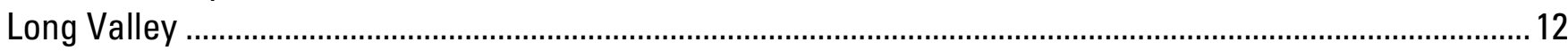

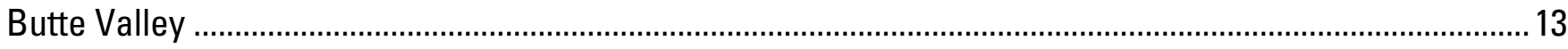

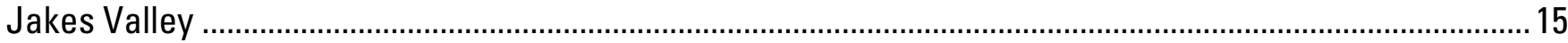

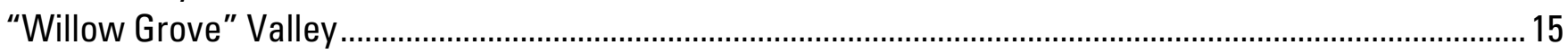

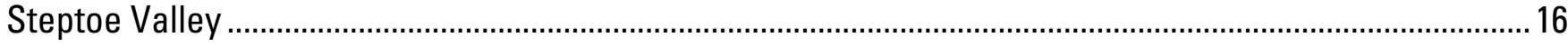

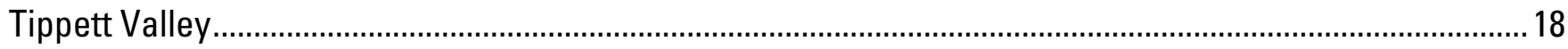

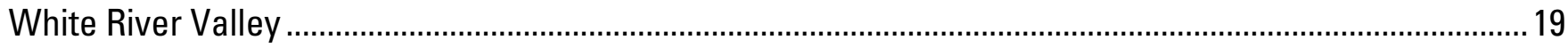

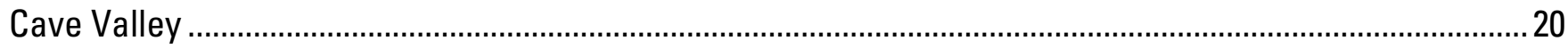

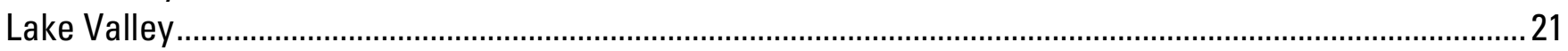

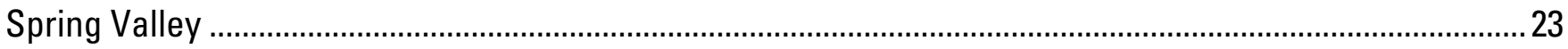

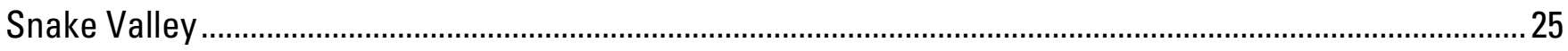

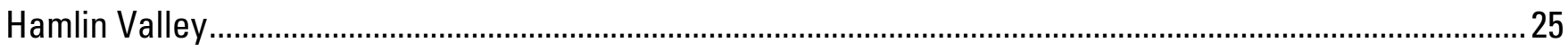

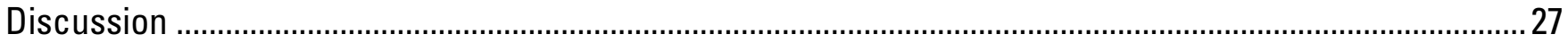

Acknowledgments

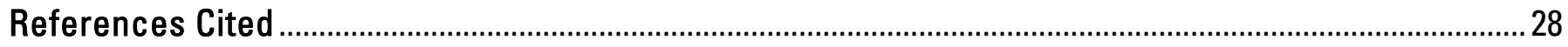

\section{Figures}

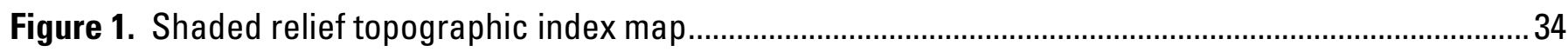

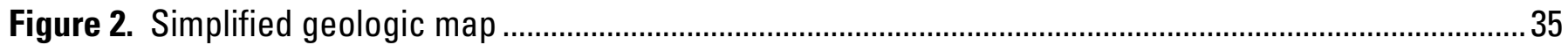

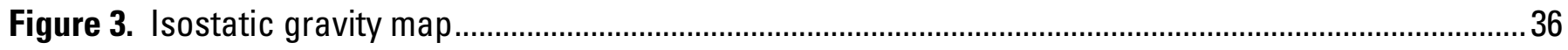

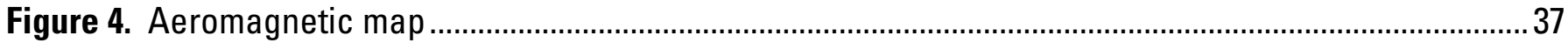

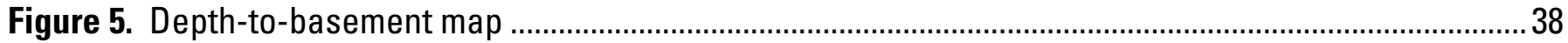

Figure 6. Basement gravity map ................................................................................................................ 39 
Figure 7. Simplified three-dimensional geologic model

Figure 8. Stratigraphic column of general basin stratigraphy

Plate 1. Isostatic gravity map and geophysical lineaments.

Plate 2. Depth-to-basement map and geologic structures 


\title{
Geophysical Framework Investigations Influencing Ground-water Resources in East-central Nevada and West-central Utah
}

\author{
By Janet T. Watt and David A. Ponce
}

\begin{abstract}
A geophysical investigation was undertaken as part of an effort to characterize the geologic framework influencing ground-water resources in east-central Nevada and west-central Utah. New gravity data were combined with existing aeromagnetic, drill-hole, and geologic data to help determine basin geometry, infer structural features, estimate depth to pre-Cenozoic basement rocks, and further constrain the horizontal extents of exposed and buried plutons. In addition, a three-dimensional (3D) geologic model was constructed to help illustrate the often complex geometries of individual basins and aid in assessing the connectivity of adjacent basins. In general, the thirteen major valleys within the study area have axes oriented north-south and frequently contain one or more sub-basins. These basins are often asymmetric and typically reach depths of $2 \mathrm{~km}$. Analysis of gravity data helped delineate geophysical lineaments and accommodation zones. Structural complexities may further compartmentalize ground-water flow within basins and the influence of tectonics on basin sedimentation further complicates their hydrologic properties.
\end{abstract}

The horizontal extent of exposed and, in particular, buried plutons was estimated over the entire study area. The location and subsurface extents of these plutons will be very important for regional water resource assessments, as these features may act as either barriers or pathways for groundwater flow. A previously identified basement gravity low strikes NW within the study area and occurs within a highly extended terrane between the Butte and Confusion synclinoria. Evidence from geophysical, geologic, and seismic reflection data suggests relatively lower density plutonic rocks may extend to moderate crustal depths and rocks of similar composition may be the source of the entire basement gravity anomaly.

\section{Introduction}

We have conducted geophysical investigations as part of an effort to help characterize the geologic framework influencing ground-water resources in the eastern Great Basin. Because regional framework studies play an important role in understanding the hydrology of the study area, geologic and geophysical studies were conducted to determine basin geometry, infer structural features, estimate depth to pre-Cenozoic geophysical basement rocks, interpret the subsurface extent of plutons, and combine all of the above into a 3D geologic model. The primary study area covers a large region in east-central Nevada and west-central Utah (fig. 1). 
The study area is composed of linear north-south trending ranges that reach elevations in excess of $3.9 \mathrm{~km}$ (Wheeler Peak) separated by asymmetric elongate basins with an average maximum depth of about $2 \mathrm{~km}$. Thirteen major valleys occur within the study area, the geologic and geophysical character of which are discussed in more detail in the basin-by-basin descriptions to follow. Most valleys strike north-south and contain one or more elongate sub-basins. The geophysical basement rocks in the study area include pre-Cenozoic consolidated and some crystalline rocks, mainly of Precambrian to early Jurassic quartzite, limestone, and dolomite and Jurassic to Tertiary plutonic rocks exposed in some places along the Nevada-Utah border (fig. 2). Unless otherwise noted, basement rocks in this report are geophysical basement rocks as defined above. Many of the volcanic units that are preserved in the intermontane basins are tuffs that were erupted from a number of caldera complexes within and surrounding the primary study area. All of the basins described in this report formed at various times during the Cenozoic, and the materials that fill the various basins range in age from Eocene to recent. Most of the rocks exposed throughout the region have characteristic density and magnetic properties such that they create a distinguishable pattern of gravity and magnetic anomalies that can be used to infer their subsurface extent and geologic structure.

\section{Generalized Geology}

A simplified geologic map of the study area is shown in figure 2 and the following geologic summary is from a number of sources (e.g. Hose and others, 1976, Tschanz and Pampeyan, 1970; Stewart, 1980; and Gans and Miller, 1983). More than $10 \mathrm{~km}$ of Precambrian to Early Jurassic strata were deposited in this part of the Cordilleran miogeosyncline (continental shelf), although strata thin toward the southeast margin of the miogeosyncline. These rocks are predominantly composed of quartzite, limestone, and dolomite with lesser amounts of sandstone, argillite, and shale.

Mesozoic rocks only occur in limited exposures in the extreme northwestern part of the study area in the Diamond Mountains (Howard, 1987). Presumably these rocks have been eroded or are the result of non-deposition during orogenic uplift that began in the Late Jurassic. Mesozoic age structures are present throughout eastern Nevada and western Utah and, in particular, include folds in Paleozoic strata in the Butte and Confusion synclinoria (fig. 2) (e.g., Hose, 1966; Hose and others, 1976; Gans and Miller, 1983).

Older Tertiary sedimentary rocks occur scattered throughout the study area and include the Eocene Sheep Pass Formation that predominantly consists of interbedded lacrustine limestone, sandstone, and shale. Miocene and Pliocene sedimentary rocks are also present throughout the region. Tertiary volcanic rocks occur throughout the study area and consist predominantly of lava flows and ash-flow tuffs. These volcanic rocks include the areally extensive Oligocene 35 Ma Kalamazoo Tuff (e.g. Hose and others, 1976; Gans and Miller, 1983; Hagstrum and Gans, 1989) in the central part of the study area, rocks from the voluminous 32 to 27 Ma Indian Peak volcanic field (Best, Christiansen, and Blank, 1989) in the southeast part of the study area, and rocks from the $\sim 24$ Ma Caliente caldera complex (Best, Christiansen, and Blank, 1989) southeast of the primary study area boundary.

Plutons have limited exposures in the region, but Jurassic, Cretaceous, and Tertiary plutonic rocks occur along the Nevada-Utah border (fig. 2), in particular along the Deep Creek 
Range, Kern Mountains, and the Snake Range. Tertiary granitic rocks are also exposed along the southern and northern Egan Range, and the Cherry Creek Range in the central part of the study area. In general, these plutons range in composition from quartz monzonite to granodiorite. Analysis of aeromagnetic anomalies in Nevada (Grauch and others, 1988), the Ely 1 x 2 degree quadrangle (Ponce, 1991), and west-central Utah (this report) indicate that plutons may be more extensive in the subsurface than their outcrop pattern suggests.

\section{Gravity and Magnetic Methodology}

\section{General}

Gravity data for the study area were derived from statewide gravity compilations of Nevada (Ponce, 1997) and Utah (Bankey and others, 1998) and augmented with over 2,000 new gravity stations (Scheirer, 2005; Mankinen and others, 2006; Watt and others, unpub. data, 2006) collected throughout east-central Nevada and west-central Utah. All gravity data were reduced using standard gravity methods (Blakely, 1995) and reduced to isostatic anomalies (Jachens and Roberts, 1981) that emphasize features in the mid to upper crust, having removed longwavelength variations in the gravity field related to topography (Simpson and others, 1986). The isostatic gravity data were gridded at $500 \mathrm{~m}(1,600 \mathrm{ft})$ and displayed as a color-contoured map (fig. 3 and pl. 1).

A residual total intensity aeromagnetic map (fig. 4) was compiled from statewide compilations of Nevada (Hildenbrand and Kucks, 1988) and Utah (Bankey and others, 1998). Aeromagnetic surveys were flown at various flight-line spacings and altitudes. Most of the study area was flown at a flight-line spacing of $0.6-1.2 \mathrm{~km}(1-2 \mathrm{mi})$ at various flight-line altitudes up to $2.7 \mathrm{~km}(9,000 \mathrm{ft})$ barometric. The southeast corner of the study area was flown at a flight-line spacing of 1.2-2.4 km (2-4 mi) and a barometric flight-line altitude of $3.6 \mathrm{~km}(12,000 \mathrm{ft})$. The northern part of the map is covered by National Uranium Resource Evaluation (NURE) aeromagnetic surveys flown at a coarse flight-line spacing of $4.8 \mathrm{~km}$ (3 mi) and a nominal flight-

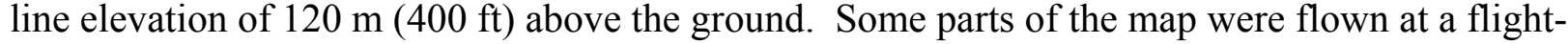
line spacing of $0.6 \mathrm{~km}(1 / 2 \mathrm{mi})$ and a nominal flight-line elevation of $305 \mathrm{~m}(1,000 \mathrm{ft})$ above the ground. Aeromagnetic data were corrected for diurnal variations of the Earth's magnetic field, despiked, and leveled. Residual magnetic anomalies were computed by subtracting an International Geomagnetic Reference Field (Langel, 1992) appropriate for the year of each survey (Hildenbrand and Kucks, 1988; Bankey and others, 1998). Individual aeromagnetic surveys were either upward or downward continued as necessary to a flight-line elevation of 305 $\mathrm{m}(1,000 \mathrm{ft})$ above the ground, adjusted to a common datum, and merged to produce a uniform map allowing interpretation across survey boundaries (Hildenbrand and Kucks, 1988; Bankey and others, 1998). Because of the coarse flight-line spacing and, in general, high flight-line elevation, the resulting magnetic map may not resolve magnetic sources lying at shallow depths beneath the surface. In addition, because of the poor quality of some surveys, caution should be exercised when interpreting short-wavelength anomalies that cross the original survey boundaries. The digital data set was gridded at an interval of $1 \mathrm{~km}$ using a minimum curvature algorithm and color contoured. 


\section{Gravity Inversion - Depth to Basement}

The regional-scale thickness of Cenozoic deposits within the study area (fig. 5 and pl. 2) was determined utilizing a modified version (Chuchel, oral commun., 2005) of an iterative gravity inversion method originally developed by Jachens and Moring (1990) that allows for the inclusion of independent constraints, such as drill-hole information, other geophysical data, as well as minimum depths to geophysical basement (e.g., drill holes that do not reach basement). The inversion process essentially separates the isostatic gravity field into two components: the gravity field generated by pre-Cenozoic basement and the gravity field generated by less-dense overlying Cenozoic deposits, including alluvial fill and volcanic deposits.

The inversion process begins by using an initial basement gravity field determined from the isostatic gravity data collected on outcrops of pre-Cenozoic basement rocks. This initial basement gravity field is only a first approximation because gravity stations measured on basement outcrops are influenced by the gravity effect of low-density deposits in adjacent basins, especially for those measurements nearest the edge of the basin. The arithmetic difference between the isostatic and basement gravity fields represents the initial estimate of the basin gravity field. The gravitational effects of this basin gravity field are removed from each gravity measurement made on basement rock, essentially removing gravity effects caused by low density basin-fill material, thus creating an improved measure of the basement gravity field. This process is repeated until successive iterations produce little or no changes in the basement gravity field. Inversion of the final basin gravity field yields the final estimate of the depth to pre-Cenozoic basement.

The inversion process is partly based on the density contrasts between Cenozoic alluvial deposits, Cenozoic volcanic rocks, and pre-Cenozoic basement. The density of basement rocks were allowed to vary horizontally, whereas, the density of Cenozoic deposits vary according to a density-depth function (table 1). In addition to these geologic and density constraints, the inversion process was constrained by limited drill-hole information and other geophysical constraints. The density-depth function used in this process is the same as that used for the entire state of Nevada (Jachens and Moring, 1990) and the Basin and Range province (Saltus and Jachens, 1995) that was based on rock sampling, geophysical logs, and borehole gravity measurements throughout the state. The state-wide density-depth function, however; may not be appropriate for individual detailed basin analysis within the study area (e.g., Scheirer, 2005; Phelps and others, 2006; and Ponce and others, 2006). Simplified geologic data were derived from state geologic maps of Nevada (Stewart and Carlson, 1978) and Utah (Hintze and others, 2000).

The inversion process to determine the thickness of Cenozoic deposits is subject to a number of limitations, including: (1) gravity data coverage; (2) accuracy of the density-depth function; (3) accuracy or scale of geologic mapping; and (4) simplifying assumptions regarding concealed geology. A more detailed discussion of the accuracy and limitations of the inversion method were provided by Jachens and Moring (1990) and Saltus and Jachens (1995). Because of the regional depth-to-basement process, limitations mentioned above, and the inherent ambiguity in the gravity method, caution should be exercised when interpreting basin thicknesses less than $500 \mathrm{~m}(1600 \mathrm{ft})$. 
Table 1. Density-depth function for Cenozoic basin fill material and volcanic rocks used in the depth-to-basement process and relative to basement rocks $\left(2.67 \mathrm{~g} / \mathrm{cm}^{3}\right)$ (Jachens and Moring, 1990).

\begin{tabular}{|c|c|c|c|c|}
\hline \multirow{2}{*}{$\begin{array}{l}\text { Depth } \\
\text { range } \\
(\mathrm{m})\end{array}$} & \multicolumn{2}{|c|}{ Cenozoic basin fill } & \multicolumn{2}{|c|}{ Cenozoic volcanic rocks } \\
\hline & $\begin{array}{l}\text { Contrast } \\
\left(\mathrm{g} / \mathrm{cm}^{3}\right)\end{array}$ & $\begin{array}{l}\text { Density } \\
\left(\mathrm{g} / \mathrm{cm}^{3}\right)\end{array}$ & $\begin{array}{l}\text { Contrast } \\
\left(\mathrm{g} / \mathrm{cm}^{3}\right)\end{array}$ & $\begin{array}{l}\text { Density } \\
\left(\mathrm{g} / \mathrm{cm}^{3}\right)\end{array}$ \\
\hline $0-200$ & -0.65 & 2.02 & -0.45 & 2.22 \\
\hline $200-600$ & -0.55 & 2.12 & -0.40 & 2.27 \\
\hline $600-1200$ & -0.47 & 2.32 & -0.35 & 2.32 \\
\hline$>1200$ & -0.37 & 2.42 & -0.25 & 2.42 \\
\hline
\end{tabular}

\section{Boundary Analysis of Gravity and Magnetic Sources}

Directional derivatives of both gravity and magnetic data were generated to define the edges or boundaries of geophysical sources. A technique (R. Simpson, oral commun., 2006) similar to that described by Blakely and Simpson (1986) was used to calculate directional derivatives, which reflect abrupt lateral changes in the density or magnetization of the underlying geology, especially where the sources are shallow. The most prominent directional derivative locations often occur over the edges of steeply-dipping features. Alignments of directional derivative locations can be used as an aid to define lineaments, faults, boundaries of geologic features, and geophysical terranes.

Prior to boundary analysis, magnetic data were first reduced-to-the-pole (e.g., Baranov and Naudy, 1964; and Blakely, 1995) and then transformed to their magnetic potentital (or pseudogravity) (Baranov, 1957). Because the regional magnetic field and the direction of magnetizations are seldom vertical, magnetic anomalies are commonly laterally displaced from their sources and may have distorted, asymmetrical shapes. This effect often increases the complexity and difficulty of magnetic anomaly interpretation. Thus, magnetic data were first reduced-to-the-pole to remove the effect of the direction of the Earth's magnetic field and the direction of magnetization by transforming the data to their expression at a vertical field and magnetization, as if measured at the north magnetic pole. Magnetic anomalies also often have a more complex form than gravity anomalies and because the two are related by a directional derivative, the magnetic field can be transformed into an equivalent gravity field (magnetic potential or pseudogravity transformation), assuming that the density distribution is proportional to the magnetization distribution. Moreover, gravity anomalies have their steepest gradients approximately over the edges of their causative sources, especially for shallow sources, thus the magnetic potential can be used to approximate the edges of magnetic sources (e.g., Grauch and Cordell, 1987; Blakely, 1995). 
In this study boundary analysis of gravity data was used to help identify prominent geophysical lineaments, distinguish accommodation zones between basins or sub-basins, and help constrain the extents of caldera margins. Geophysical lineaments were identified based on the magnitude and continuity of the directional derivative locations. Note that the boundary analysis highlights the most prominent directional derivatives, which often occur over the edges of steeply-dipping features. Caldera margins were modified after Stewart and Carlson (1996) based on boundary analysis of gravity data. Boundary analysis of magnetic sources was used to infer the horizontal extent of exposed and buried granitic plutons. In this report, "pluton extent" refers to the horizontal extent of a pluton in plan view. Pluton extent was inferred based on the methods of Grauch and others (1988).

\section{Discussion}

\section{Lineaments}

Geophysical lineaments (fig. 3 and pl. 1) were defined on the basis of alignment of steep horizontal gradients of gravity data and in many cases these lineaments correlate to geologically mapped faults and accommodation zones between depocenters. Most basins within the study area were defined by two basin-bounding faults; one on either side of the basin. The main basinbounding fault, as defined by analysis of isostatic gravity data (fig. 3 and pl. 1), was often located outboard from the fault defined from surface geologic mapping, (fig. 2 and pl. 2) revealing a shallow pediment along the basin margins. The location of the gravity gradient may simply be highlighting the normal fault with the most vertical offset, and thus the greatest density contrast between basement rock and alluvial fill. This shift may reflect the fault history of the individual basins, with faulting migrating towards the range-front through time (Langenheim, 2005). Alternatively, in some areas, the basinward shift of the gravity gradient may be the result of concealed slide blocks within the basins.

Although basins are aligned north-south for the most part, there are a number of indentations and inflections along the basin margins that correspond to sub-basin boundaries and gravity lineaments (fig. 3). The gravity lineaments associated with these irregularities in the main basin boundaries were interpreted as accommodation zones if the lineament separated sub-basins with distinctly different types of extension, amounts of extension, or opposing dips based on geological and geophysical evidence. Basin dip was inferred from a combination of geologic, drill-hole, and depth-to-basement information. Abrupt changes in basin geometry likely reflect contrasting stress regimes among sub-basins. The transfer of stress from one sub-basin to another occurs within these accommodation zones.

\section{Extent of Plutons}

The horizontal extent of exposed and concealed granitic rocks throughout the region can be inferred using potential-field methods (fig. 4) (Grauch and others, 1988; Grauch, 1996), however, the relationship between geophysical anomalies and plutons is complex, and, in part is related to the physical properties of the intrusive rocks and their contrast with the surrounding rocks. Of particular importance are their magnetic properties, which can be highly variable in the eastern Great Basin. 
Except for weakly magnetic rocks along the eastern part of Nevada (fig. 4), inferred boundaries of plutonic rocks correlate well with mapped geology (e.g., Egan Range, Schell Creek Range) (Stewart and Carlson, 1978; Hintze, 1980). The weakly magnetic granitic rocks of eastern Nevada are of Jurassic and Cretaceous age and are predominantly composed of quartz monzonite and include one of the largest intrusive bodies in the eastern Great Basin - an unusual two-mica granitic body in the Kern Mountains (Best and others, 1974; Hose and others, 1976, Lee and others, 1981). Other, essentially non-magnetic, two-mica granitic bodies occur in the Snake Range and these rocks may be the result of anatexis of thick accumulations of Precambrian to Lower Cambrian clastic rocks (Lee and others, 1981) along the Cordillera miogeocline. These or similar weakly magnetic plutonic rocks may be concealed throughout the region as first discussed by Blakely (1988), are difficult to detect, and are potential barriers to ground-water flow (Plume, 1996) provided fracturing is limited.

Lower Cretaceous intrusive rocks (Stewart and Carlson, 1978) discontinuously span an east-west corridor from Ely to Eureka, Nevada and are moderately magnetic and easily delineated using magnetic methods (box, fig. 4). Tertiary plutons have variable magnetic properties throughout the region, based on their aeromagnetic expression. Aeromagnetic data indicate the southern and northern Egan Range, as well as the Cherry Creek Range to the north, are underlain by one or more extensive Tertiary plutons.

Based on their aeromagnetic expression, plutonic rocks may also be present as the underlying intrusive equivalents of the Indian Peak and Caliente caldera complexes (fig. 4). In addition, lower density, essentially non-magnetic plutonic rocks may be present in the mid to upper crust throughout a region defined by a basement gravity low between the Butte and Confusion synclinoria (fig. 6) (Hose, 1966; Hose, 1977).

\section{Basement Features}

A basement gravity map of the study area (fig. 6), derived by removing the effects of Cenozoic deposits, emphasizes lateral density variations in the pre-Cenozoic basement rocks throughout the region. Although some remnant artifacts may be present in the basement gravity map, in general, basement gravity features transcend Basin and Range structures, suggesting the gravity effects of the Cenozoic deposits were removed reasonably well in the depth-to-basement process. The basement gravity map is particularly useful for defining pre-Cenozoic structures and crustal-scale geophysical domains.

In a statewide analysis of basement gravity anomalies in Nevada, Blakely and Jachens (1991) show that a basement gravity low extends across the central part of the state, correlates with middle to late Tertiary volcanic rocks, and may reflect concealed silicic intrusions within the mid to lower crust. Within the study area, this prominent basement gravity low (fig. 6) strikes NW and transects the study area and shows little correlation with exposed pre-Cenozoic rocks (Stewart and Carlson, 1978; Hintze and others, 2000). The western margin of the basement gravity low is surprisingly linear and trends about $\mathrm{N} 30^{\circ} \mathrm{W}$, a direction similar to that of the northern Nevada rift (NNR, Zoback and others, 1994), a mid-Miocene feature in the extreme western margin of the study area that may have preferentially followed a pre-existing basement structure (Ponce and Glen, 2002; 2005). 
Much of this basement gravity low occurs in a highly extended terrane between two structural troughs - the Butte and Confusion synclinoria (Hose, 1966; Hose, 1977; Gans and Miller, 1983), composed of downfolded Triassic to Permian rocks. Although, the areally extensive Oligocene Kalamazoo Tuff is also entirely enclosed by the two synclinoria (Hagstrum and Gans, 1989) and the basement gravity low, it is probably not a cause of the basement gravity low because of its limited total volume. The Butte synclinorium correlates to the western margin of the basement gravity low, whereas, the Confusion synclinorium is just east of the basement gravity low and directly correlates to a basement gravity high over the Confusion Range, Burbank Hills, and Mountain Home Range in western Utah (Hintze and others, 2000). The disconnect between the gravity anomaly polarity of the two synclinoria may be related to underlying lithologic differences between the two areas such as the presence of concealed silicic intrusions or differences between the sedimentary packages.

In the southeast part of the study area, the basement gravity low correlates to the Indian Peak and Caliente caldera complexes (Best, Christiansen, and Blank, 1989) and may be related to underlying intrusions, or may in part, be related to the incomplete removal of the gravity effects of the Cenozoic volcanic rocks in this area. A steep EW-trending basement gravity gradient in the southern part of Hamlin Valley indicates a prominent change in lithology in this region from Paleozoic carbonate terrane to the north and the Indian Peak volcanic terrane to the south.

Many of the mapped eastern Nevada peraluminous granitic bodies, such as those in the Kern Mountains and Snake Range (Best and others, 1974) and other granitic bodies in the Egan Range, for example, occur within the broad basement gravity low. This suggests relatively lower density plutonic rocks extend to moderate crustal depths and rocks of similar composition may be the source of the basement gravity anomaly (e.g. Blakely, 1988; Blakely and Jachens, 1991). Intrusions may also have been imaged in the middle and lower crust within the basement gravity low by a COCORP seismic reflection line across the northern Schell Creek Range (fig. 6) (Hauser and others, 1987), and help explain the absence of any offset of the Moho by the crustalscale Schell Creek fault. Given that extension post-dates emplacement of these plutons throughout eastern Nevada, they may have weakened the crust and set the stage for subsequent extension. Although the origin and exact nature of the basement gravity low is enigmatic, it may reflect silicic intrusions (Blakely, 1988) or prominent changes in the lithology of pre-Cenozoic rocks in eastern Nevada and western Utah. The lateral changes in lithology associated with these intrusions at mid to upper crustal levels may influence ground-water flow in the deep-seated carbonate-rock aquifer system in the eastern Great Basin.

\section{D Geologic Model}

A simplified 3D geologic model of the study area (fig. 7) was derived from surface geology, the inversion of gravity data (fig. 5), and a thickness of volcanic units map (Sweetkind and du Bray, in press). This simplified model is unfaulted and consists of 3 layers: top of Cenozoic alluvium (topography), top of volcanic rocks, and top of pre-Cenozoic basement rocks.

The three layers that make up the model were produced using a combination of geophysical and geologic modeling software, including Northwest Geophysical Associate's GMSYS $^{\circledR}$ Profile, Geosoft's Oasis Montaj ${ }^{\circledR}$, and Dynamic Graphic's Earth Vision ${ }^{\circledR}$ (EV) software 
packages. The top of the pre-Cenozoic basement was derived from a gravity inversion process used to determine the thickness of pre-Cenozoic sediments and volcanic rocks (described above in the Gravity and Magnetic Methodology section). Aggregate thickness of volcanic rocks in the study area was estimated by summing isopach grids of the major tuffs of the Caliente and Indian Peak caldera complexes; as well as the Kalamazoo, Shingle Pass, Monotony, and Windous Butte tuffs. While this compilation of volcanic rocks does not represent all the volcanic rock units in the study area, it is our best estimation at this time. The top of Cenozoic alluvium is represented by the topographic surface, which in this case was created from the $30 \mathrm{~m}$ DEMS of Nevada and Utah. All surfaces were regridded to $2 \mathrm{~km}$ for use in EV. No faults were included in this preliminary model although steep gradients in the basement surface approximate fault offset of pre-Cenozoic rocks against basin-filling alluvium and volcanic rocks.

The resulting model helps illustrate the often complex geometries of individual basins and aids in assessing the connectivity of adjacent basins. Currently, cross-sections exported from this model are being used to help answer important water resource questions as to the extent of the surficial aquifer in the study area and as to the potential for connectivity of that aquifer between adjacent basins (L. Knochenmus, oral commun., 2006). This model could be greatly improved with the incorporation of drill-hole information and regional geologic cross-sections that provide more detail of the different pre-Cenozoic basement units.

\title{
Geologic and Geophysical Basin-by-basin Descriptions
}

\author{
By Alan R. Wallace, Janet T. Watt, and David A. Ponce
}

\section{Basin stratigraphy and tectonics}

All of the basins described in this report formed at various times during the Cenozoic, and the materials that fill the various basins range in age from Eocene to recent. In general, basin-filling units include Eocene sedimentary rocks, Oligocene volcanic tuff and flow units, Miocene sedimentary rocks, and poorly to unconsolidated Pliocene and Quaternary sediments (fig. 2), although not all basins contain all of these units. The Eocene units are part of the Sheep Pass Formation, which was deposited in a series of shallow, broad basins in eastern Nevada (Potter and others, 1995). The resulting sedimentary rocks commonly are present in the basins that coincide with the locations of the Eocene basins and absent in those that do not. However, depending on the age and style of formation of the intermontane basin, as well as the events that took place after the deposition of the Sheep Pass strata and the formation of the younger basin, the Sheep Pass may be absent.

Volcanic rocks were erupted from a variety of sources. Many of the volcanic units that are preserved in the intermontane basins are tuffs that were erupted from caldera complexes, such as the Indian Peak complex southeast of Lake Valley, the Kalamazoo caldera in the northern part of the Schell Creek Range, and other complexes outside of the study area (Best and others, 1989a). The locus of volcanic activity migrated south with time. Upon eruption, the outflow tuff units commonly follow the paleotopography, filling valleys and leaving highlands 
uncovered. As a result, the distribution and thicknesses of the tuff units can vary considerably. Flow units, such as basalt and andesite, tend to be more localized near the eruptive centers. As with the tuffs, the paleotopography commonly determines their ultimate distribution and thicknesses. In addition, the calderas themselves have steep margins and are filled with thick sequences of highly welded tuffs. The presence or absence of volcanic rocks within the basins depends on these primary distributions, the age of volcanism relative to basin formation, and any post-volcanism, pre-basin erosion.

Many of the Miocene sedimentary units were shed from highlands during various stages of uplift, including the formation of detachment and related listric faults. The clast lithologies reflect the compositions in the source areas, which in this region include a wide variety of rock types, and the grain size depends on the energy of the stream systems and the distance from the source area. For example, sediments transported into the basin from a topographically high source area will be coarser near the range front and finer grained farther into the basin. In addition, many of these basins formed during uplift of adjacent ranges, and the composition, grain size, and dip of the resulting strata can vary considerably up section. Ash deposits derived from numerous eruptions in southern Idaho also blanketed this area in the Miocene (Perkins and others, 1998). This ash was deposited in the basins during fluvial sedimentation, and they also landed in the highlands, to be reworked and carried into the basins with other sediments. Thus, some beds within the basin can be composed of pure air-fall ash, and others can contain considerable amounts of reworked ash. Evaporite deposits, such as anhydrite, are common in Miocene basins in southern Nevada, but they are known only in the Hamlin Valley (Alam and Pilger, 1991). These deposits form in evaporative playa environments in the middle of a basin.

The youngest strata in the basins are Pliocene and Quaternary sedimentary deposits. These include clastic sediments that were deposited in alluvial fans adjacent to the range fronts, and playa and lake deposits in the middles of the valleys. Because of climate changes through this period of time, the central parts of the valleys contained alternating fluvial and playa/lake environments (Reheis, 1999). This created vertically alternating beds of fine-grained and coarsegrained materials.

All of the intermontane basins in this study area are fault controlled, but the tectonic events varied with time and space. Faulting related to the formation of the Snake Range detachment system in the northern part of the area produced abundant normal faults, some of which originally dipped to the west and were then rotated to east-dipping positions by later extensional faulting (Gans and Miller, 1983). The Snake Range system was active episodically from the middle Eocene into the middle Miocene, although many of the normal faults that formed the basins were active in the late Oligocene to middle Miocene (Miller and others, 1999). Similar detachment faulting in the Grant Range area, west of the White River Valley, was active in the middle Miocene (Lund and others, 1993). Faulting has continued into the Pliocene and Quaternary, enhancing the steepness of some of the range fronts and producing Pleistocene and younger scarps (Dohrenwend and others, 1996). In the northern part of the area, most of the faulting occurred after volcanism; in the southern part of the area, it occurred before.

Because some of the faulting pre-dated Miocene sedimentation, pre-Miocene units commonly are more tilted and deformed than the Miocene units. As tectonism continued and 
then waned through the Miocene, dips of the Miocene strata decrease up-section, leading to the generally horizontal sediments that were deposited since the late Miocene.

In the basin descriptions that follow, the distributions of the broad geologic units and major faults are based on the state geologic map (Stewart and Carlson, 1978), with more specific additions from larger-scale maps and studies where available. Isotopic dates on volcanic units are derived from a wide variety of published to unpublished compilations and studies that, in general, are not specifically cited. Subsurface lithologies identified from drilling data are from Hess (2004). Dohrenwend and others (1996) provided the locations and general ages of late Cenozoic faults in the study area. Unless otherwise noted, refer to plates 1 and 2 for the following discussion.

\section{Basin geophysics}

The geophysical character of individual basins varies throughout the study area, but there are common structural fabrics among some valleys. Most valleys' axes run north-south and contain one or more elongate sub-basins. According to estimates based on the inversion of regional gravity data, most basins reach depths of about $2 \mathrm{~km}$; some exceed $4 \mathrm{~km}$ in depth and the deepest basin depths occur in northern Steptoe and Lake Valleys. With the exception of Steptoe Valley, the basins in the southern portion of the study area are deeper than those in the north. Some of the valleys contain basins that have characteristic half graben structure with a dominant range-front fault on one side of the basin. However, these faults, as identified by gravity data, are often located outboard of the topographic range front. Some valleys are more symmetric, with a graben located along the valley axis with shallow pediments on either side. A number of valleys, especially the longer ones (e.g., Steptoe and Spring Valleys), contain several sub-basins that have different extensional dynamics, in between which, transfer zones have developed to accommodate differential extension.

\section{Little Smoky Valley}

Lower Paleozoic carbonate rocks underlie the Fish Creek Range on the northwest side of the valley, while Upper Paleozoic siliciclastic units and a thin sequence of west-dipping Tertiary volcanic rocks underlie the Pancake Range to the northeast. These siliciclastic and volcanic units appear to dip west beneath the valley floor, but the sub-basin relation between these units and the carbonate-dominated section exposed in the Fish Creek Range is unknown. Oligocene (35.5 Ma) volcanic rocks are widely exposed on the southern fringe of the basin, with scattered exposures on the eastern, northeastern, and northern margins of the basin. Miocene sedimentary units are exposed locally along the eastern margin of the basin, and, on the basis of drilling data, likely are present within the basin fill. The northern half of the valley contained Pleistocene lakes (Reheis, 1999), and Quaternary sediments cover the entire basin. Drilling data indicate that there are no volcanic rocks within the basin fill, and that Paleogene sedimentary units are locally present beneath the Miocene and Quaternary units.

Gravity data suggest that Little Smoky Valley is composed of two sub-basins. The depth to basement is up to $2 \mathrm{~km}$ in the northern sub-basin, although most of the sub-basin is $<1 \mathrm{~km}$ deep. Gravity data suggest a west-dipping valley floor. A small, partially buried, north-trending basement high separates the northern and southern sub-basins. The southern sub-basin is shallow, with a maximum depth of $1 \mathrm{~km}$ in a narrow zone between the buried basement high and 
the Fish Creek Range to west; an east-dipping with a significant amount of movement is likely present along the east side of the range. A number of undifferentiated late Cenozoic faults and some Holocene faults cut Quaternary lake deposits at the north end of the basin. Gravity data indicate another semi-buried, north-trending Paleozoic-cored basement high at the north end of the valley near Black Point, separating Little Smoky and Newark Valleys.

\section{Newark Valley}

Newark Valley is bounded on the west by the Diamond Mountains, which are characterized by east-dipping upper Paleozoic siliciclastic and carbonate units. Buck Mountain and bedrock areas to the east contain upper and lower Paleozoic units. Some Oligocene to early Miocene (36-20 Ma) volcanic rocks and minor Miocene sedimentary units (likely ash rich) are present at the south end of the valley. Paleogene sediments are exposed at the north end of the valley within the valley itself. None of the oil-well drilling logs in the valley differentiate any of the Tertiary and Quaternary units ("valley fill"), so the presence or absence of volcanic rocks or Paleogene sediments is unknown. Newark Valley contained Pleistocene lakes except in the southeast arm of the valley, east of the Pancake Range (Reheis, 1999).

Gravity data show a north-trending, shallowly buried basement ridge connecting southern Buck Mountain and the northern Pancake Range, creating two main sub-basins (eastern and western). The eastern sub-basin is between 1 and $3 \mathrm{~km}$ deep, and the basin is deepest on the west side. Gravity data support geologic evidence that an east-dipping normal fault controlled the east side of the basement ridge and created a west-dipping sub-basin. Most of the western subbasin is $<1 \mathrm{~km}$ deep. The western sub-basin can be further divided into three sub-basins (northern, central, and southern) separated by a northwest-trending basement high visible in gravity data. The southern sub-basin is shallow ( $<2 \mathrm{~km}$ at its deepest). The central sub-basin, located adjacent to Diamond Peak, is up to $5 \mathrm{~km}$ deep, with the deepest parts of the elongate basin on the western margin of Newark Valley. The central sub-basin appears to shallow to the north to $<500 \mathrm{~m}$ and then deepen again to $4 \mathrm{~km}$, however; gravity data coverage is sparse in this area and therefore the apparent gravity high may be an artifact. The northern portion of the western sub-basin straddles the study area boundary and is separated from the central basin by a narrow, northwest-trending basement high visible in the gravity data and supported by the presence of Miocene sediments and Paleogene volcanic rocks and sediments recovered in drill holes (Hess, 2004). This sub-basin is elongate, up to $4 \mathrm{~km}$ deep, and appears to dip towards the east. The change from westward-dipping to eastward-dipping sub-basins suggests that an accommodation zone separates the central and northern sub-basins (fig. 2).

\section{Long Valley}

The Butte Mountains form the eastern margin of Long Valley and are composed of almost entirely east-dipping upper Paleozoic carbonates. Alligator Ridge and the Maverick Springs Range to the west are generally underlain by east-dipping upper and lower Paleozoic units. Eocene (36 Ma) volcanic rocks are exposed at the northwest end, west side, and south end of the valley. Tertiary rocks are not present on the Butte Mountains side of the valley. Quaternary fill covers most of the valley surface except for small windows of tuffaceous sedimentary rocks (likely ash rich) along the west side. Most of the valley contained Pleistocene lakes (Reheis, 1999); hence the Quaternary fill includes lacustrine sediments in these areas. 
Gravity and drilling data indicate that the basin is asymmetric, dipping to the east. Basin depths range from $<1 \mathrm{~km}$ on the west side to up to $4 \mathrm{~km}$ in the east-central part of the basin, and depths decrease to $1.5 \mathrm{~km}$ in the north. The entire southern half of the basin has depths $<1 \mathrm{~km}$. Pekarek (1988) reported that seismic data showed a depth of up to $8,000 \mathrm{ft}(2.4 \mathrm{~km})$ in the valley. Depths to Oligocene volcanic rocks range from 140-580 $\mathrm{m}$ (460 to 1,900 ft) and have thicknesses of $60-740 \mathrm{~m}$ (194 to 2,434 ft), consistently thinning to the north from the center of the basin. The presence of these volcanic rocks is confirmed by aeromagnetic data (fig. 4).

Undifferentiated late Cenozoic faults are present along the entire western base of the Butte Mountains. Pekarek (1988), on the basis of seismic data, indicated that this fault system is significant, with more than $8000 \mathrm{ft}(2.4 \mathrm{~km})$ of offset. Maximum horizontal gradients in gravity data line up along the base of the Butte Mountains, confirming the existence of a steeply dipping normal fault (fig. 3). Mapping by Gans and Seedorff (2000) in the Antelope Pass area at the south end of the valley shows north-striking faults and north-plunging folds that involve Paleozoic, Oligocene, and Miocene units. These structures undoubtedly project into the southern part of the valley beneath the valley fill; however, these structures are not visible in the potential field data.

\section{Butte Valley}

East-dipping upper Paleozoic carbonates dominate the Butte Mountains to the west of Butte Valley. The Cherry Creek Range and the northern Egan Range to the east are characterized by complexly faulted, west-dipping upper and lower Paleozoic units. Eocene volcanic rocks (34$36 \mathrm{Ma}$ ) are extensively exposed at the south end of the valley, locally along the western basin margin, and in the north-central part of basin. Exposures of these volcanic rocks are visible as relatively high-amplitude magnetic anomalies in the aeromagnetic map (fig. 4). These volcanic rocks are overlain by Quaternary deposits in the northern part of the valley. Tertiary tuffaceous sedimentary rocks are exposed in small areas at the southern and northern ends of the basin. A late Pleistocene lake was present in the central part of Butte Valley (Reheis, 1999). Seismic data indicate that Butte Valley overlies the eastern limb of a broad syncline in the Paleozoic rocks (fig. 6, Butte synclinorium of Hose (1977); see also Gans and Miller (1983), Smith and others, (1991)).

Gravity data, coupled with geology and topography, indicate four sub-basins within Butte Valley (northern, north-central, south-central, and southern), as well as a shallowly buried basement high between the south-central and southern sub-basins. The northern three sub-basins are on the west side of the Cherry Creek Range. The basement high extends southwest from the southern Cherry Creek Range, across the valley north of Hunter Flat, to the central Butte Mountains. The southern sub-basin underlies the valley floor from Hunter Flat to the southern end of Butte Valley.

The northern sub-basin is an elongate, north-trending basin that straddles the study area boundary. Basin depths reach $4 \mathrm{~km}$ in a small area right at the study area boundary. This subbasin appears have a central graben, the edges of which are delineated by maximum horizontal gradients in gravity data.

A northwest-trending gravity high separates the northern and north-central sub-basins. The gravity data show that the axis of the northern sub-basin is farther east than that of the north- 
central sub-basin. This suggests that the northwest-trending gravity high is a structural accommodation or transfer zone between the two sub-basins. The north-central sub-basin appears to dip gently to the north until it deepens steeply to $4 \mathrm{~km}$ at its northern margin along the proposed transfer zone. Two drill holes at the northern end of the north-central sub-basin indicate 400-500 m (1300-1700 ft) of Quaternary and Neogene fill, underlain by 100-500 m (400 to 1600 $\mathrm{ft}$ ) of volcanic or volcaniclastic rocks (Hess, 2004). These data were used to constrain the depthto-basement inversion.

The gravity data highlight an east-northeast-trending gravity high separating the northcentral and south-central sub-basins. The data indicate that the south-central sub-basin is deepest along its northern margin, suggesting the existence of a fault with down-to-the-south displacement. Alternatively, the distinction in the gravity data between these two sub-basins may have to do with the presence of Tertiary volcanic rocks beneath the northern sub-basin. The gravity inversion method may be underestimating the basin depths in the northern sub-basin because of the presence of dense volcanic rocks.

A northeast-striking, northwest-dipping normal fault likely coincides with the northern boundary of the gravity high that separates the southern and south-central sub-basins. This fault is the southwest projection of a fault along the northwestern side of the Cherry Creek Range, which represents a basin-and-range fault along the northwest side of that range, as shown in Hose and others (1976). The south-central sub-basin is arcuate in shape and appears to dip to the east-southeast, with depths increasing from $<500 \mathrm{~m}$ to $4 \mathrm{~km}$. The arcuate nature of the sub-basin likely reflects the interplay between normal faulting along the base of the Butte Mountains and right-lateral offset on its northern margin within the accommodation zone between the southcentral and north-central sub-basins.

A northeast-trending basement and gravity high divides the southern and south-central sub-basins. Gravity data suggest the high likely reflects buried upper Paleozoic basement rocks. The basement high is bounded by two northeast-striking faults, one of which is described above. The other fault, along the southern side of the high, has about $2 \mathrm{~km}$ of down-to-the-southeast offset, and it extends from the southwestern Cherry Creek Range into the Butte Mountains (Hose and others, 1976). The location of this fault corresponds to a steep northeast-trending gravity gradient in Butte Valley. The fault also may continue southwest to US 50 at Illipah and merge with the east-dipping normal fault along the east side of the White Pine Range. This fault generally is the extension of a "basin and range fault" shown by Hose and others (1976) in the Cherry Creek Range and an Oligocene low-angle normal fault that may have been reactivated in the late Miocene (Gans and Miller, 1983). The Egan Range slid off the Cherry Creek Range during initial formation of this fault, which might be the breakaway fault for an east-dipping detachment beneath the Snake Range detachment (Wernicke and Axen, 1988). The southern sub-basin appears to dip to the north with depths ranging from $1 \mathrm{~km}$ to $3 \mathrm{~km}$ adjacent to the northeast-striking fault. One drill hole in the southern sub-basin indicates $191 \mathrm{~m}(625 \mathrm{ft})$ of Quaternary and Neogene fill and $294 \mathrm{~m}$ (946 ft) of pre-Neogene volcanic rocks (Hess, 2004), which agrees with depth-to-basement estimates from gravity data.

The connection to Jakes Valley to the southwest is a shallow basement high with a modest thickness of Paleogene volcanic rocks capping Paleozoic units. The distribution of these volcanic rocks corresponds to relatively high-amplitude magnetic anomalies. Air photos show a 
northwest-trending fabric, and northwest-striking faults may cut through this area. The depth to pre-Cenozoic basement is $<500 \mathrm{~m}$ across this divide. The connection to the Smith Valley arm of Steptoe Valley to the southeast is similarly very shallow and capped by Paleogene volcanic rocks. This connection trends southeast, parallel to the apparent faults and thus may be fault controlled.

\section{Jakes Valley}

The White Pine Range to the west and the Butte Mountains and Egan Range to the east of Jakes Valley are composed entirely of east-dipping upper Paleozoic carbonates. Paleogene volcanic rocks are extensive at the northeast margin of the valley, and some Neogene sediments (likely ash rich) are exposed along the eastern and southeast margins, where they are overlain by Quaternary sediments. Quaternary sediments cover most of the valley. The central portion of the valley contained a late Pleistocene lake (Reheis, 1999).

Gravity data indicate a shallow, north-south-trending basin, up to $1 \mathrm{~km}$ (largely $<500 \mathrm{~m}$ ) deep, with a small area in the southeast part that is up to $1.5 \mathrm{~km}$ deep. This basement depth is constrained by a single drill hole (Hess, 2004). The west side of the valley is likely bounded by an east-dipping normal fault, and undifferentiated Quaternary and Tertiary faults are present along this range front. Several Holocene faults strike northeast across the west-central part of the valley, and displacement to the southeast possibly created the slightly deeper (up to $1.5 \mathrm{~km}$ ) south-central part of the basin.

\section{“Willow Grove” Valley}

At the northwest end of White River Valley is a shallow, unnamed valley herein designated as Willow Grove Valley. Oligocene volcanic rocks (31-35 Ma) form a semicircular rim around much of the outer half of Willow Grove Valley, with a more central core of Neogene sediments overlain by Quaternary deposits in the middle of the valley. The eastern side of the valley is a narrow rim cored by Paleozoic rocks with a cap of Oligocene volcanic rocks. As such, this is not a true sedimentary basin, although it is a topographic basin. Depth-to-basement estimates suggest a thick sequence of volcanic rocks with fairly consistent depths of between 500 $\mathrm{m}$ and $2 \mathrm{~km}$ throughout the valley (fig. 5). Depths reach a maximum of $6 \mathrm{~km}$ along the southeastern basin margin. It must be noted that gravity data coverage in this basin is fairly sparse. This may be a Tertiary volcanic center, perhaps a caldera, with a central Neogene sedimentary basin. The basin was not drilled. Drilling in northern White River Valley indicates $720 \mathrm{~m}(2,350 \mathrm{ft})$ of Tertiary volcanic rocks overlying several hundred feet of basal conglomerates (see comments for White River Valley), suggesting a thick sequence of volcanic rocks next to an eruptive center. There are also several regional ash flow tuffs in the vicinity.

The Currant Summit shear zone controls the southern edges of this valley and the Oligocene volcanic rocks. This zone is a steep, oblique transfer fault with significant sinistral movement that was active in the Tertiary and Quaternary. Net slip on the northern side was about $3.3 \mathrm{~km}$ to the west (Williams and Taylor, 2002). This shear zone may be part of the Pritchards Station lineament (Ekren and others, 1976), which is extensive to the west. The eastern projection of this shear zone into northern White River Valley is unknown. Transfer zones, by nature, are not necessarily laterally continuous for great distances, and the relatively small amount of offset along this fault may indicate a relatively short strike length. 


\section{Steptoe Valley}

The ranges to the east and west of Steptoe Valley are underlain by upper and lower Paleozoic units. Mesozoic and Tertiary granitic and dioritic intrusive rocks are exposed along the western margin of the valley. Oligocene (33 Ma) volcanic rocks are exposed along the northwestern flanks of the Schell Creek Range, in the Currie Hills at the north end of the valley, and along the eastern side of the Egan Range at the south end of the valley (Gans and others, 1989). Epiclastic Paleogene sedimentary rocks underlie the volcanic rocks in the southern Egan Range and in the Currie Hills. Miocene sedimentary units are exposed only at the northernmost end of the valley; they are fine-grained, ash-bearing lacustrine units with some clastic interbeds (A. Wallace, unpubl. data, 1993). The valley did not contain any Pleistocene lakes (Reheis, 1999), which differs from other valleys in the region. The absence of a lake indicates either substantial downward percolation into the basin sediments or, less likely given the elevation of the lowest sills, outflow from the valley during the Pleistocene. Quaternary sediments cover the entire valley floor. Discussion of Steptoe Valley will be divided into two sections: a description of the valley north of Ely, and a description of the valley south of Ely.

The portion of Steptoe Valley north of Ely is underlain by Quaternary sediments, Miocene sedimentary units, and Oligocene (33-36 Ma) volcanic rocks. Seismic data (Smith and others, 1991) and geologic data (Gans and Miller, 1983) show that the Steptoe Valley basin north of Ely is asymmetric and dips to the west. A moderately east-dipping normal fault forms the eastern base of the Egan Range. A steeper high-angle fault with less apparent offset forms the western base of the Schell Creek Range. Both of these range-front structures are visible in the gravity data. Holocene and other late Cenozoic faults are present along the entire eastern base of the Egan Range. Both Smith and others (1991) and Gans and Miller (1983) indicate that Paleogene volcanic and sedimentary rocks at depth in the valley dip much more steeply than the overlying Quaternary and Neogene sedimentary and volcanic rocks, although dip values are not provided.

The valley north of Ely appears to be composed of at least three main sub-basins: northern, central, and southern. The east side of the Egan Range south of the Elko-White Pine County border, has two prominent, fault-controlled topographic concavities, one related to the southern sub-basin just northwest of McGill and the second related to the central sub-basin at Cherry Creek. Gravity data indicate that the basin is significantly deeper adjacent to these concavities and shallows between the southern and central sub-basins. The data suggest that the formation and morphology of these two sub-basins were controlled by faulting along the range front, and that the sub-basins dip to the west. Based upon studies along major rift zones, such as the Rio Grande and East African rifts (Chapin and Cather, 1994; Rosendahl, 1987), the structural geometry and the gravity data suggests that a structural accommodation zone within the basin, extending northeast from the Egan Range, separates the southern and central sub-basins. The northern edge of the central sub-basin may appears to have northwest-trending structural control, based on the gravity and topographic data. These relations suggest that the structural geometry of this part of Steptoe Valley is much more complex than is evident at the surface.

The northern sub-basin is east of the steep, northwest-trending front of the Cherry Creek Range. Late Cenozoic faults follow the steep base of the range front, but are not highlighted in gravity data. Oligocene volcanic rocks are exposed along the eastern side of the valley and appear to dip southwest into the basin. Gravity data indicate that the deepest part of the basin is 
southwest of the volcanic and Paleozoic exposures at Currie, although the depth to basement is less than $2 \mathrm{~km}$, considerably less than the northern end of the central sub-basin to the south. As such, the northern sub-basin is shallow and may dip gently to the southwest into the range-front faults along the Egan Range.

The central sub-basin in Steptoe Valley corresponds to the concavity in the Egan Range at Cherry Creek. This part of the valley appears to be further subdivided into three sub-basins that deepen to the north, with the first basin up to 3-km deep, the second up to 5-km deep, and the third largest basin up to 7-km deep. All of these sub-basins appear to dip to the west towards the range-front fault at the base of the Egan Range. Gravity data and basin lithologies in the central sub-basin are constrained by two drill holes near the shallower margin of the northernmost sub-basin (Hess, 2004). Drilling data indicate 790 to $940 \mathrm{~m} \mathrm{(2,600} \mathrm{to} \mathrm{3,100} \mathrm{ft)} \mathrm{of}$ basin fill (Quaternary and Neogene) and 1,200 to 1,300 m (3,900 to 4,200 ft) of Oligocene volcanic rocks; Paleozoic basement was encountered at a depth of about 2,100 m (6,900 ft).

The southern sub-basin, located near McGill, may be composed of two structurally controlled segments. The northern segment is east of the range-front concavity, where it is widest and deepest. This part of the sub-basin is up to 4-km deep in the center and shallows to $<1.5 \mathrm{~km}$ to the north and south. Drilling data in this sub-basin indicates about $640 \mathrm{~m}(2,100 \mathrm{ft})$ of Quaternary and Neogene material, $670 \mathrm{~m}(2,200 \mathrm{ft})$ of volcanic rocks, and $305 \mathrm{~m}(1,000 \mathrm{ft})$ of underlying clastic sediments (Tertiary(?) North Creek Formation); these Paleogene sediments may correspond to sediments (Ts1, Stewart and Carlson, 1978) exposed beneath volcanic rocks in the Schell Creek Range to the east. A seismic line across the sub-basin shows a steep, eastdipping normal fault along the west side of the basin (Gans and others, 1985; and Miller and others, 1999), which corresponds with a steep northeast-trending gravity gradient and asymmetric, west-dipping basin geometry (Figs. 3 and 5). This fault may be the breakaway fault for the Snake Range detachment (Bartley and Wernicke, 1984), which is extensively exposed in the Snake Range to the east. This northern segment thins towards and terminates at the proposed northeast-trending accommodation zone between the southern and central sub-basins. The southern segment of the southern sub-basin is defined by an elongate deep basin east and south of McGill. Gravity data indicate that the sub-basin at depth in this area is narrow and as much as $5 \mathrm{~km}$ deep at its southern end. North-striking faults control the east side of Heusser Mountain, and the major faults along the Egan Range project along the west side of the mountain. As such, this narrow part of the basin, as well as Heusser Mountain, may be a small horst and graben on the southern shoulder of the southern sub-basin. As described below, a northwest-trending accommodation fault likely terminates both the basin and the mountain, perhaps creating considerable structural complexity at the south end of this sub-basin.

Steptoe Valley south of Ely is composed of one large sub-basin that, like the basin to the north, may have two segments. The northern segment, which is immediately southeast of Ely, is small and relatively shallow ( $<2-\mathrm{km}$ depth). The southern segment, which comprises the majority of the sub-basin, is located outboard of a concavity in the Schell Creek Range, a range front that contains late Cenozoic faults. This sub-basin is up to 4-km deep near the Schell Creek Range and elongate in a northwest direction. Although the gravity data are symmetric around the gravity low, the deepest part of this sub-basin is closer to the Schell Creek Range (fig. 5). In addition, the gravity and geologic data indicate that the basin east of the Egan Range may be a broad, east-dipping, thinly buried pediment surface. As such, this sub-basin appears to dip to the 
east into the fault-controlled Schell Creek Range, in contrast to the west-dipping basins that comprise the northern part of the valley.

Overall, it appears that Steptoe Valley is composed of several structurally controlled subbasins that reflect diverse geometries of range-front faulting in the Egan and Schell Creek Ranges. The shift to the south from an Egan to Schell Creek influence on basin formation, as well as the opposing basin dips in those two areas, also suggests the presence of a major accommodation zone between the northern and southern parts of the valley. Similar reversals in the polarity of basin dip are common in modern rift settings, as described above. This accommodation zone likely extends from the area between Ely and Heusser Mountain southeast to and connecting with the range-front fault system along the southern Schell Creek Range. The existence of gravity highs in this area further supports this argument.

\section{Tippett Valley}

Tippett Valley, between the Antelope Range to the west and the Kern Mountains and Deep Creek Range to the east, is the southern part of Antelope Valley. A low, volcanic-cored ridge bisects the basin northeast of Baldy Peak in the Antelope Range, creating Tippett Valley to the south. The Antelope Range is underlain by a west-dipping, structurally complex sequence of Paleozoic rocks and overlying middle Tertiary volcanic rocks. The Kern Mountains and Deep Creek Range are a complex mixture of Paleozoic sedimentary rocks that were intruded by Cretaceous plutons and overlain by west-dipping middle Tertiary volcanic rocks (Nelson, 1966). Quaternary sediments, including those deposited in a late Pleistocene lake (Reheis, 1999), cover the valley floor. Miocene sedimentary units are widespread to the northeast along the west side of the Deep Creek Mountains, where they overlie the middle Tertiary volcanic rocks; these units contain abundant deposits of fine-grained air-fall ash (Perkins and others, 1998). On that basis, similar strata likely are present between the Quaternary sediments and volcanic rocks within the Tippett Valley basin. Seismic data in the Goshute Valley, $70 \mathrm{~km}$ to the north, confirm the presence of Miocene strata at depth in that area (Strecker and others, 1996). The only drill hole in the valley was at the eastern margin, and it indicates about $360 \mathrm{~m}(1200 \mathrm{ft})$ of Tertiary volcanic rocks above the Paleozoic basement (Hess, 2004).

Normal faults, some of which were reactivated in the late Pleistocene (Dohrenwend and others, 1996), control the steep eastern side of the range. These faults down-dropped the Paleozoic and Tertiary rocks into the western part of the basin, and these units are exposed in a series of hills in the southwestern (Red Rocks) and southern (Red Hills) parts of the valley. This belt of exposures curls to the east and connects with more extensive bedrock units in the western Kern Mountains. North-striking faults with late Cenozoic movement cut and partially control the stratigraphy in the Red Hills. A major down-to-the-south fault controls the south side of the Kern Mountains and projects into the northern Red Hills area. This fault, coupled with the northstriking faults in the Red Hills, indicate that the southern margin of the basin is extremely structurally complex. A second fault divides the Kern Mountains and southern Deep Creek Mountains, and it projects into the southern part of the basin. Both of these faults are related to middle Tertiary detachment-related faulting and thus have complex histories and geometries (Rodgers, 1987).

The westerly dip of the volcanic rocks on the east side of the basin suggests that the basin dips to the west towards the range-front faults along the Antelope Range. However, the gravity 
data indicate that the deepest part of the basin is elongate to the north-northeast and is beneath the center of the valley, not more to the west side as might be expected with a west-dipping syntectonic basin. Using data and interpretations of the Goshute Valley as an analog, the central, deeper part of the valley may reflect early sedimentation along the axis of the basin during Miocene extensional sagging. Later asymmetric expansion of the basin by range-front faulting, with sediment inflow from the adjacent ranges, tilted the basin and created a wider but thinner sequence of basin sediments. Alternatively, pre-Miocene units are thicker in the middle of the basin than on the margins.

Gravity data also indicate that the basin is composed of two sub-basins. The northern of the two is elongate to the north-northeast; it is deepest at its south end, reaching a depth of $6 \mathrm{~km}$, and gradually shallows to the north. The southern sub-basin is located northwest of the Kern Mountains; it is more circular in shape and reaches a depth of $3 \mathrm{~km}$. The fault that bounds the north side of the Kern Mountains projects through the gravity high that separates the two subbasins, indicating a possible structural control on the formation of the two sub-basins.

\section{White River Valley}

The Egan Range forms the eastern boundary of the valley and is composed of southeastdipping Paleozoic rocks, with patches of Oligocene volcanic rocks on the west side. Volcanic rocks are fairly extensive at the south end of the range between White River and Cave valleys. Kellogg (1964) shows a normal fault (White River fault) along the west side of the range. The Eocene Sheep Pass Formation (Potter and others, 1995) is exposed beneath the Oligocene volcanic rocks at the top of the range, and they also are present beneath Quaternary alluvium in White River Valley. Kellogg estimated 2,530 m (8,300 ft) of down-to-the-west offset along the White River fault.

The west side of the valley is bounded by the Grant Range, which is composed of generally east-dipping Paleozoic rocks and Paleogene sedimentary and volcanic rocks. Miocene sedimentary rocks (Horse Camp Formation) are exposed near the northwest end (Horton and Schmitt, 1996). The east side of the range is extremely complex structurally, with numerous west-directed but east-dipping detachment faults (Lund and others, 1993). The maximum extension occurred at about $14 \mathrm{Ma}$, synchronous with deposition of the Horse Camp Formation.

Quaternary sediments cover most of the valley, ramping gradually west onto the Grant Range. Three north-trending, east-dipping half grabens are present in the White River Valley basin (fig. 5; Potter and others, 1991). These grabens were produced by two north-striking faults in the center of the basin and the White River fault along the east side of the basin. The faulting produced several horsts of Paleogene and older rocks that are exposed in the center of the valley, especially at the south end. Published cross sections based on oil-well drilling data show that the Sheep Pass Formation is juxtaposed against Paleozoic rocks beneath the Quaternary cover. No late Cenozoic lake was present in the valley (Reheis, 1999).

Gravity data suggest that White River Valley is composed of three large sub-basins (northern, central, and southern) and one small sub-basin (western) within the study area. The northern sub-basin is located just east of Willow Grove Valley and appears to dip gently to the east. This sub-basin is up to 4-km deep and is elongate in a north-northeast direction. Near Lund, the basin depth reaches $4 \mathrm{~km}$ and gradually shallows to $<500 \mathrm{~m}$ near the northern margin of the 
sub-basin. A west-dipping normal fault was mapped along the western base of the Egan Range in both the northern and central sub-basins (Kellogg, 1966). The northern sub-basin is separated from the central sub-basin by a wedge-shaped gravity high that may reflect the presence of an accommodation zone. The central sub-basin is a half graben that dips steeply to the east towards the range front fault system at the base of the Egan Range (Potter and others, 1991). Basin depths reach up to $6 \mathrm{~km}$ along the fault, but they shallow rapidly to $<500 \mathrm{~m}$ to the west. There are no drill holes in the deepest part of this sub-basin to confirm these depths, but there are a number of drill holes around its margins. Gravity data depict the western sub-basin as a relatively shallow $(<3 \mathrm{~km})$ east-dipping half graben. In contrast to the other sub-basins, the southern sub-basin dips to the west and curves to the southeast, forming an arcuate sub-basin that follows the White River around to the east and then to the south between the Seaman and North Pahroc Ranges south of Cave Valley. The southern sub-basin is up to 5-km deep at its northern margin, but it shallows southeastward to an average depth of $3 \mathrm{~km}$. The valley takes a sharp turn southward outside the study area. This sharp turn corresponds to a rapid shallowing and narrowing of the basin, which may reflect the existence of an accommodation zone. In addition, there may be a shallow $(<500 \mathrm{~m})$ basin connection between White River Valley and Garden Valley to the southwest based on depth-to-basement estimates.

\section{Cave Valley}

A northeast-trending horst south of Shingle Pass divides Cave Valley into two subbasins. East-dipping Miocene sediments, Oligocene (33-34 Ma) volcanic rocks, and Eocene clastic sediments are extensively exposed in the Egan Range west of the northern sub-basin, and Paleozoic rocks underlie Mt. Grafton to the east. Kellogg (1964) described the Miocene sediments as fluvial and tuffaceous, with a thickness of $600 \mathrm{~m}(2,000 \mathrm{ft})$ near Shingle Pass. Oligocene volcanic rocks (29-33 Ma) and Eocene strata underlie the southern end of the southern sub-basin, and comprise parts of the Schell Creek Range to the east. A late Pleistocene lake covered the southern part of the southern sub-basin (Reheis, 1999). One drill hole in the northern part of the northern sub-basin encountered 1,000 m (3,400 ft) of Quaternary and Neogene units underlain by $424 \mathrm{~m}(1,400 \mathrm{ft})$ of Eocene clastic sediments of the Sheep Pass Formation (Hess, 2004). One hole near the north end of the southern sub-basin penetrated $360 \mathrm{~m}$ $(1,200 \mathrm{ft})$ of Quaternary sediments, $424 \mathrm{~m}(1,400 \mathrm{ft})$ of Miocene sediments, and $212 \mathrm{~m}(700 \mathrm{ft})$ of Eocene clastic sediments (Sheep Pass Formation). No volcanic rocks were noted in either hole, which is unusual considering that volcanic units are exposed extensively to the west of both sub-basins and that this area likely received large quantities of air-fall tuffs during volcanic eruptions just to the east (Kellogg, 1964; Best, Christiansen, and Blank, 1989). However, the lack of prominent magnetic anomalies in Cave Valley confirms the absence of volcanic materials in the drill holes in both sub-basins (Hess, 2004). A seismic line that extended through the southern sub-basin shows that the Eocene units dip more steeply than the overlying sediments (Potter and others, 1991). Minor late Cenozoic faults are present along the western margin of the northern sub-basin, but none are present along the margins of the southern sub-basin.

Paleozoic rocks in the Schell Creek Range dip moderately to the east, as do Tertiary volcanic rocks and underlying Paleozoic rocks in the Egan Range to the west. This indicates substantial fault displacement along the east side of the northern sub-basin to downdrop the Oligocene and Miocene rocks. However, this fault is not evident in the gently southwest-dipping 
morphology of the sub-basin. It does suggest that the $<1 \mathrm{~km}$ of late Cenozoic sediments dip much less and in the opposite direction than the underlying Tertiary volcanic rocks. In addition, the dip of the northern sub-basin contrasts with the easterly dip of the southern Steptoe sub-basin to the north. This suggests a transfer or accommodation zone striking northwest from north of Mt. Grafton in the Schell Creek Range.

Field reconnaissance by D. Sweetkind and C. Potter (oral commun., 2006) and a caldera map of Ludington and others (1996) suggest that the southern sub-basin might, in part, be a buried $\sim 33$ Ma caldera, with mega-breccias in the "andesite and related rocks" sequence (unit $\mathrm{Ta}_{2}$, Stewart and Carlson, 1978) at the south end of the valley. The drilling data in the central and southern part of the sub-basin show only "surface valley fill" above the Paleozoic basement, whereas the drilling records from the well near the north end of the sub-basin did not report any volcanic rocks between the Miocene and Eocene sediments. The seismic line in the central part of the southern sub-basin extends through the deepest part of the sub-basin and indicates an eastdipping basin floor and subparallel Cenozoic units above it (Potter and others, 1991). As such, any caldera would have to be south of this line. A possible small caldera or eruptive center just southwest of the valley could explain nearby megabreccias and related volcanic rocks and is evidenced by a subtle isostatic gravity low and circular topographic feature $\sim 11 \mathrm{~km}$ in diameter.

A northeast-trending, southeast-dipping $\left(\sim 35^{\circ}\right)$ Paleozoic-cored horst bisects the basin and separates the gently northwest-dipping northern sub-basin from the southeast-dipping subbasin to the south. Kellogg (1964) shows a northeast striking fault at Shingle Pass, with as much as $4 \mathrm{~km}$ of offset down to the northwest. This fault extends north-northeast beneath Quaternary sediments and likely produced the southeast dip of the basement high. The seismic line through the center of the southern sub-basin indicates one and possibly two steeply west-dipping faults along the western side of the Schell Creek Range (Potter and others, 1991). Kellogg (1964) reported between 2.1 and $4.2 \mathrm{~km}$ of offset along this fault and showed that this fault ends at the Shingle Pass fault.

Gravity data indicate that the northern sub-basin is very shallow $(<500 \mathrm{~m})$, with the suggestion that the basin floor dips gently to the northwest, reaching a maximum depth of 1.5 $\mathrm{km}$, corresponding to the drill-hole data in the northern part of the sub-basin that show $1.5 \mathrm{~km}$ $(4,800 \mathrm{ft})$ of Cenozoic sedimentary units. The gravity data indicate that the southern sub-basin dips steeply to the southeast, reaching depths of 4-7 km in the southeastern part. This depth, coupled with the similar depth estimate of $6 \mathrm{~km}$ in the seismic line (Potter and others, 1991), contrasts with the drilling data north and south of the line that show no more than $2 \mathrm{~km}$ of basin fill above the Paleozoic basement. A more detailed, and likely more accurate, depth-to-basement map of Cave Valley was determined by Scheirer (2005) based on a basin-specific density-depth function.

\section{Lake Valley}

East of Lake Valley, upper Paleozoic rocks dip to the west at the south end of the Fortification Range and northeast at the north end towards Lake Valley Summit. The northern sequence overlies east-dipping lower Paleozoic rocks exposed in the southern Schell Creek Range and Grassy and Dutch John Mountains west of the Lake Valley. East-dipping Oligocene volcanic rocks and underlying Eocene sediments are exposed in the southern Fortification Range 
(Loucks and others, 1989) and in the Fairview Range south of Kixmiller Pass. The volcanic rocks on the far west side of the Fortification Range, west of a northwest-striking, west-dipping normal fault, dip to the west. The Fortification Range is cut by numerous other east- and westdipping normal faults (Loucks and others, 1989), some with significant (>1 km) offset. These faults cut both Paleozoic and mid-Tertiary rock units and extend beneath Quaternary sediments into southern Spring Valley and northeastern Lake Valley. Faulting of Miocene-age units within the basin fill is possible, depending on the age of the faults.

The northern margin of the Indian Peak caldera complex ( 32-27 Ma), which underlies the Wilson Creek and Fairview Ranges, cuts east-northeast through the Atlanta district (Best, Christiansen, and Blank, 1989), and the Fortification Range volcanic rocks are outflow units from that complex and other eruptive centers (Loucks and others, 1989). The northern margin of the caldera extends roughly west-southwest beneath Lake Valley just north of Pony Springs (Best, Christiansen, and Blank, 1989), wraps around the west side of the Fairview Range, arcs southeast through about Bristol Pass, and follows the west side of Lake Valley to near Pioche before turning eastward. Thus, much of the southern half of Lake Valley, which from now on will be referred to as Patterson Valley, is underlain by the caldera, and the ring fault separates volcanic caldera fill from older rocks outside the caldera.

Limited drilling in the northern part of Lake Valley, north of the caldera margin, conflicts somewhat with the surrounding surface geology. Near, but apparently outside the buried caldera margin, no volcanic rocks or Eocene sediments were encountered beneath 1,700 ft of "valley fill." North of this well, a second well penetrated $518 \mathrm{~m}$ (2,200 ft) of "valley fill" and $823 \mathrm{~m}$ $(2,700 \mathrm{ft})$ of volcanic rocks above the Paleozoic basement. These drilling results agree with aeromagnetic data, which show magnetic anomalies in northern Lake Valley corresponding with the location of the northern well, but not in central Lake Valley near the southern well. Outflow from caldera eruptions commonly concentrates along paleotopographic lows; this might explain the variable locations of volcanic rocks outside the caldera, although the pronounced thickness difference over such a short distance is somewhat unusual.

Gravity data show that Lake Valley is composed of three main sub-basins (northern, central, and southern). Depth-to-basement estimates indicate the elongate center of the northern sub-basin is more than $6 \mathrm{~km}$ deep, shallowing quickly to the east and west to less than $1 \mathrm{~km}$. The northern sub-basin dips to the west against an east-dipping range from fault along the eastern Schell Creek Range, with a small, west-dipping normal fault in the middle of the northern subbasin. The northern and central sub-basins have opposing dips, suggesting they are separated by an accommodation zone. The central sub-basin is much shallower, with an average depth of $<2$ $\mathrm{km}$, and dips gently to the east. The southern sub-basin is located south of Pony Springs and the Indian Peak Caldera boundary in Patterson Valley. Aeromagnetic data suggest Patterson Valley is filled with highly magnetic volcanic rocks, and the gravity data support this, showing basin depths throughout the valley ranging from 2 to $5 \mathrm{~km}$ deep with major depocenters east of Bristol Pass and northeast of Pioche. The divide between northern Lake Valley and Patterson Valley coincides with the interior of the caldera, with volcanic rocks on either side. Although not clearly reflected in the gravity, these rocks may produce a low-relief but resistant subsurface barrier that has produced the two basins since at least the Pleistocene. 
Quaternary lacustrine deposits are exposed in the valley floor of the northern half of the valley. The center of the northern part of Lake Valley contained an elongate, valley-parallel late Cenozoic lake (Reheis, 1999). The headward incision of Patterson Wash into Quaternary units in the southern half of the valley has extensively exposed the underlying late Miocene to Pliocene Panaca Formation (Phoenix, 1948). The Panaca Formation is lacustrine with marginal and interfingering fluvial deposits, and it formed when Meadow Valley Wash was dammed behind volcanic rocks near Caliente, producing a northward-expanding playa and shallow lake. How far north this lake extended along Lake Valley beyond the present exposures is unknown. Gravity data (fig. 5) show that the floor of Patterson Valley deepens to the north, while the topography is nearly flat, permissively suggesting that the Pliocene lake could have extended a considerable distance up the valley. However, the possible buried volcanic high noted above may have prevented the lake from expanding north beyond the current drainage divide. Panacaequivalent sediments, now covered by Quaternary units, may have been deposited in a separate sub-basin in the northern part of the valley.

\section{Spring Valley}

The Snake Range contains an arched detachment fault, with ductily deformed metamorphic rocks in the footwall and highly faulting and rotated Paleozoic sedimentary rocks in the hanging wall. The overall configuration of the detachment system is an antiform, dipping westward on the west side of the range. Miller and others (1999) indicate some west-dipping normal faults along the west side of the range, but these are subsidiary to the one along the east side of the Schell Creek Range. The Schell Creek Range contains generally west-dipping Paleozoic and Neoproterozoic sedimentary rocks that are cut by moderately east-dipping normal faults, as well a numerous more flat-lying faults related to early detachment (Gans and others, 1985). The Snake Range detachment underlies the Schell Creek Range and Spring Valley at a depth of 5-8 km. One of the east-dipping normal faults controls the eastern base of the Schell Creek Range and has displaced Tertiary and Quaternary rocks down at least $2 \mathrm{~km}$ in the northcentral part of the basin. Spring Valley is covered by Quaternary sediments, and a late Pleistocene lake covered most of the valley (Reheis, 1999). Thus, lacustrine sediments are present at and near the surface throughout much of the valley.

Gravity data indicate that most of Spring Valley is less than $1 \mathrm{~km}$ deep (fig. 5) and can be separated into three shallow sub-basins (north, central, and south), as well as one deep basin at the far northern end of the valley between the Antelope Range and the northern Schell Creek Range. The deep, northernmost basin is somewhat elongate in a northeast direction and up to 5 $\mathrm{km}$ deep. The significant change in basin geometry from the northernmost sub-basin to the subbasins to the south suggests a northeast-trending accommodation zone where a ridge of Tertiary volcanic rocks separates this basin from the rest of Spring Valley to the south. Volcanic rocks that overlie Paleozoic rocks on the west side of the Antelope Range dip to the west, and faults, some with late Cenozoic movement, control the east side of the northern Schell Creek Range. This suggests that the basin dips to the west, although the deepest part of the basin is centered on the central part of the valley. A more detailed depth-to-basement map of Spring Valley was determined by Mankinen and others (2006).

The northern of the three shallow sub-basins extends southward to Hwy 50 and is confined to a narrow (5-10 km-wide) zone near the center of the valley. Seismic data across this 
sub-basin (Gans and others, 1985) show that the basin fill dips gently to the west, with the deeper, older units dipping somewhat more steeply than the upper, younger units, which are nearly horizontal. A drill hole near this seismic line penetrated 3,600 ft $(1.1 \mathrm{~km})$ of upper Cenozoic sediments, $400 \mathrm{~m}(1,230 \mathrm{ft})$ of Oligocene volcanic rocks, and $300 \mathrm{~m}(870 \mathrm{ft})$ of lower Tertiary (?) sediments (Hess, 2004). A second drill hole due west of Sacramento Pass (south of the seismic line) penetrated $1.3 \mathrm{~km}(4,100 \mathrm{ft})$ of undifferentiated valley fill (Hess, 2004). The northern and central sub-basins are separated by what appears to be an east-trending structural high associated with Rattlesnake Knoll (Mankinen and others, 2006). The central sub-basin is very shallow $(<1 \mathrm{~km})$ except for a small circular depocenter or structural low, up to $2 \mathrm{~km}$ deep, at its southern margin. The central and southern sub-basins are separated by an east-west-trending basement high visible in the gravity data. The southern sub-basin, roughly between the Fortification Range (west) and the Limestone Hills (east), is up to 2-km deep.

Late Cenozoic fault scarps follow the western side of the valley north of about Majors Place, along Hwy 50, and Holocene scarps are present well outboard from the range front, generally from North Spring Point south of Majors Place north to the east side of Black Mountain. In contrast, late Pleistocene faults follow the western base of the southern Snake Range, on the east side of the southern sub-basin. A middle Tertiary rhyolite is exposed outboard of the Schell Creek Range along Hwy 50 east of Majors Place, along the line of Holocene faults. The rhyolite and Paleozoic knobs to the south near North Spring Point suggest that the area between the Holocene faults and the Schell Creek range front to the west may be a more shallowly buried pediment, with an east-dipping, north-striking fault on the east side, within the basin.

Alluvial fans along the sides of the Spring Valley are very steep except over the possible pediment zone, which may have created a more diffuse "runoff ramp." This difference in fan morphologies also might reflect the abundance of more permeable carbonates in the range west of the pediment, as compared with areas along the rest of the valley that are flanked by lesspermeable metamorphic rocks, thereby influencing the amount and rate of runoff from the ranges into the valley.

Because of the complex extension-related faulting between about 34 and $12 \mathrm{Ma}$, the middle Tertiary units deeper in the basin very likely are much more complexly faulted and tilted than is evident at the surface or in the one seismic line. In addition, they are more complexly deformed than the overlying Miocene and younger units. This structural difference between early Tertiary and late Tertiary units pertains to most of the basins in the study area. Faults in the Paleogene units beneath Spring Valley dip to the west but have apparent reverse movement.

Oligocene volcanic rocks dip eastward from the Fortification Range beneath the Quaternary fill in the southern sub-basin, and Paleozoic rocks in the Limestone Hills dip to the east as well. This suggests that the southern sub-basin dips to the east, a dip in part created by a west-dipping fault along the west side of the Limestone Hills. This easterly dip contrasts with the westerly dip of the other sub-basins to the north. This dip reversal suggests that an east-westtrending accommodation zone extends across the valley from the north end of the Hills. 


\section{Snake Valley}

The Snake Range is underlain almost entirely by complexly faulted, primary to highly metamorphosed Paleozoic sedimentary rocks, with both Mesozoic and middle Tertiary intrusive rocks (Miller and others, 1999). Much of the deformation is related to the formation of the Cenozoic Snake Range decollement (e.g., Miller and others, 1983). The main arch of the detachment is in the northern Snake Range, with metamorphic grade decreasing to the north and south. The Confusion and Conger Ranges east of Snake Valley are entirely unmetamorphosed Paleozoic sedimentary rocks that contain folds and thrusts, but which overall form a broad syncline (fig. 5; the Confusion synclinorium of Hose, 1966; 1977). Volcanic rocks are notably absent in and near this valley and flanking ranges. West-dipping Miocene orogenic sediments are exposed east of Sacramento Pass (Martinez, 1999) and may extend into the main part of Snake Valley, such as exposures west of Baker. Similar Miocene sediments are exposed between the northern Snake and Kern Mountains (Rodgers, 1987).

Gravity data indicated that Snake Valley is composed of three main sub-basins (northern, central, and southern). The northern sub-basin is located east of the Deep Creek Range and reaches depths of up to $4.5 \mathrm{~km}$ along the western edge of the sub-basin. The northern and central sub-basins are separated by a east-west-trending gravity high. The two sub-basins are offset, possibly as a result of deformation along an east-west-trending accommodation zone. The central sub-basin is rather shallow $(<3 \mathrm{~km})$ and very narrow east of the Kern Mountains, but widens and deepens significantly to the south. The main depocenter is south of Gandy and northwest of the Conger Range, with basin depths up to $5 \mathrm{~km}$. The central and southern sub-basins are separated by a shallow $(<500 \mathrm{~m})$ east-northeast-trending basement ridge. The southern sub-basin, which is centered on Hwy 50, is circular with a diameter of $\sim 19 \mathrm{~km}$ and basin depths up to $3 \mathrm{~km}$. A more detailed depth-to-basement map of Snake Valley was determined by Mankinen and others (2006).

Seismic and geologic data indicate moderately east-dipping normal faults along the east side of the Snake Range and none along the Confusion Range. Offset along the normal faults is relatively minor. McGrew (1993) shows about $2 \mathrm{~km}$ of slip on the fault along the northeastern side of the southern Snake Range. His cross section shows west-dipping Miocene rocks in the western part of Snake Valley, a small exposure of Paleozoic carbonate rocks, and then a very thin skin of lacustrine deposits eastward to the northwestern end of the Mountain Home Range. Thus, much of Snake Valley, at least at this latitude, is underlain by pediment cut into preTertiary rocks and buried by a thin sequence of late Cenozoic sediments. Lake Bonneville extended south into the valley to about Baker, and related lacustrine sediments are present in that part of the valley.

\section{Hamlin Valley}

The Snake and Mountain Home Ranges and Limestone Hills surrounding Hamlin Valley contain east- to southeast-dipping lower Paleozoic sedimentary rocks, primarily carbonates but also some quartzites. The margin of the Indian Peak caldera complex cuts south-southeast from the southern end of the Limestone Hills, passing about 3-4 miles south of Hamlin well into the middle of the valley (Best, Christiansen, and Blank, 1989). Outflow units from this and related calderas cap the Mountain Home Range, and almost all rocks in the White Rock Mountains and 
Indian Peak Range are volcanic, with some Miocene sediments. The middle of the valley is covered by Quaternary and Pliocene alluvium (Best and others, 1989b).

New gravity data, combined with seismic and drill-hole data, indicate that Hamlin Valley is composed of three sub-basins (north, central, and south). Interpretation of seismic and gravity data by Alam $(1990,1991)$ indicates that the northern sub-basin is shallow and dips gently to the west; it is bounded on the west side by the Snake Range decollement and related hanging-wall normal faults. New gravity data confirm Alam's observations, showing that the northern subbasin is very shallow $(<1 \mathrm{~km})$ in most areas with a narrow, north-trending paleo-valley that is up to $3 \mathrm{~km}$ deep. This elongate sub-basin extends north into southern Snake Valley. A small basement high is present in the valley (northwest projection of Needle Point in the Mountain Home Range), with a second small, shallow, west-dipping basin to the east.

According to seismic data (Alam, 1990), the central part of Hamlin Valley is a westdipping half graben, bounded on the west side by a listric east-dipping normal fault running along the base of the Limestone Hills. A relatively minor west-dipping normal fault is present in the middle of the basin. The eastern range front of the Limestone Hills is subdued and serrate, with alluvial fans fingering into the range, suggesting the normal fault is somewhat outboard (east) of the actual range front. This observation is confirmed by regional gravity data. Depth to basement estimates suggest the central sub-basin dips to the northwest and parallels the Limestone Hills. This sub-basin is up to 5-km deep at its northern end, but the eastern part of the sub-basin is very shallow $(<500 \mathrm{~m})$. Drilling data from three wells in the central sub-basin reached Paleozoic rocks at depths of $900 \mathrm{~m}(3,060 \mathrm{ft})$ to more than $2.3 \mathrm{~km}(7,500 \mathrm{ft})$. The wells indicate 500-800 $\mathrm{m}(1,600-2,600 \mathrm{ft})$ of Quaternary and Tertiary sediments, underlain in two wells by $500 \mathrm{~m}(1800 \mathrm{ft})$ of "anhydrite." In two wells, this is underlain by 100-200 $\mathrm{m}$ (460-630 $\mathrm{ft}$ ) of volcanic rocks above Paleozoic basement. In the third well, the anhydrite is underlain by $550 \mathrm{~m}(1,820 \mathrm{ft})$ of conglomerate and claystone, $15 \mathrm{~m}(50 \mathrm{ft})$ of volcanic rocks, $150 \mathrm{~m}(500 \mathrm{ft}) \mathrm{of}$ claystone, and $300 \mathrm{~m}(1,000 \mathrm{ft})$ of tuffs, bottoming in the tuffs without reaching Paleozoic basement. Alam (1990) divided the Quaternary and Tertiary units into three groups, the oldest related to Miocene detachment faulting (and containing the anhydrite) and the younger two related to ongoing and subsequent higher-angle normal faulting and graben formation. A fourth

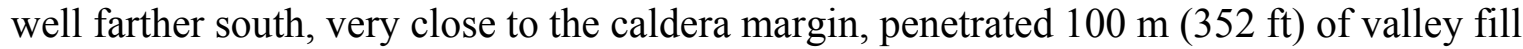
before hitting the underlying Paleozoic rocks. The presence of thick anhydrite layers is unusual at this latitude, given the temperate and moist climate, although evaporate deposits are fairly common in Miocene sedimentary basins in southernmost Nevada.

The northern and central basins are separated by a shallow $(<1 \mathrm{~km})$ basement high. The geometries of these two sub-basins, as visible in gravity data, are quite different, suggesting contrasting structural control. Alam (1990) proposes several closely spaced, east-striking sinistral high-angle accommodation faults within the northern sub-basin. Gravity data suggest the presence of a northwest-striking, southwest-dipping normal fault along the eastern margin of the central sub-basin. This northwest-striking fault may be truncated by the supposed younger eastwest striking accommodation faults of Alam (1990). The central sub-basin deepened during postdetachment normal faulting and thus received more basin sediments in the late Cenozoic. The northern sub-basin apparently did not have nearly as much late normal faulting, remained a basement high, and received less sediment. 
Best, Christiansen, and Blank (1989) suggest that the 30.6 Ma Cottonwood Wash Tuff was erupted from a caldera in the central part of Hamlin Valley, east of the Limestone Hills. One drill hole in that part of the valley did penetrate more than $305 \mathrm{~m}(1000 \mathrm{ft})$ of volcanic rocks without hitting basement, but two nearby wells penetrated only 140-192 m (460-630 ft) of volcanic rocks above the Paleozoic basement (Hess, 2004). Although the caldera could be north of these wells, the depth to basement is somewhat shallower there and drill-hole data and seismic data do not show evidence of a caldera beneath the late Cenozoic sedimentary units.

The southern sub-basin, extending southeast into Utah, is underlain by the Indian Peak caldera complex, with volcanic rocks in the ranges to the east, south, and west. Previous mapping in the area generally focused on the geology of the bounding ranges and did not present any details of the geology of the basins, including the locations or presence of range-bounding faults. However, the map of the southern Mountain Home Range (Best, Hintze, and Homes, 1987) does show a significant west-dipping fault outboard of the west side of the range, although the cross section has limited geologic control. This fault is not shown on maps of adjacent areas. The southern part of the sub-basin reaches a depth of $3 \mathrm{~km}$. Basin depths likely reflect a much thicker volcanic sequence in this area rather than a deeper post-volcanic basin. The basin appears to dip gently towards the southwest with a very shallow $(<500 \mathrm{~m})$ eastern margin.

\section{Discussion}

On the basis of regional geologic maps (Stewart and Carlson, 1978; Hintze and others, 2000), the geology of the intermontane basins in east-central Nevada and west-central Utah appears to be very simple, with a blanket of unconsolidated late Cenozoic sediments and few intra-basin faults. However, the results of numerous studies in the basins and adjacent mountain ranges summarized in this report clearly show that the cover of young sediments conceals extremely complex stratigraphy and structure in the basins. Furthermore, the geologic events that affected this region varied widely in time and space, and the geologic features of the basins that resulted from these events also vary considerably from basin to basin.

The basin summaries highlight two major points. First, the basin stratigraphy varies considerably both within and between basins, and the nature and composition of the units are equally variable. These differences reflect the varied processes that affected these areas. Thus, some basins, or parts of basins, contain a very simple sequence of Miocene and younger sedimentary units, whereas others contain the full complement of Eocene through Quaternary sedimentary and volcanic units. Similarly, the thickness of the basin fill varies from very thin to many kilometers, both within and among basins. Tectonism, topography, and source lithologies also had strong influences on the nature and distribution of the Miocene and younger fluvial units that comprise the upper parts of the basins. While most basins contained Pliocene and younger lakes, others; such as Steptoe Valley, did not.

The second major point focuses on the structural complexity of many of the basins that is not readily apparent from the regional geologic maps. The gravity data clearly demonstrate the presence of sub-basins within most of the intermontane valleys. Seismic profiles, drilling data, and geologic evidence from the adjacent ranges provide evidence of the dip and stratigraphy within each sub-basin. This structural diversity, including the formation of accommodation zones and opposing basin dips, is a product of the equally complex Cenozoic tectonic history of 
the region. These relations are very similar to those in well-studied rift systems, such as the Rio Grande and East African (e.g. Chapin and Cather, 1994; Rosendahl, 1987), which is not surprising given that this area and those rifts are products of similar crustal extension.

These intermontane basins play an important role in the hydrology of the region. Instead of being lithologically and structurally simple aquifers, these basins have complex and diverse hydrogeologic properties. The sedimentary units range from fluvial conglomerates to ash-rich lacustrine beds, and the volcanic rocks include thick, densely welded tuffs to multiple lava flows. As such, the variable hydrolithologic properties likely compartmentalize fluid flow within the basin fill. While the basal lithologies of most of the basins are unknown, a variation in the composition of these basal lithologies likely affects the hydrologic connection to the underlying pre-Tertiary basement rocks. The structural complexity of the basins, such as the concealed accommodation zones and reversed sub-basin dips, also may further compartmentalize groundwater flow within the basins. The influence of the tectonism on basin sedimentation, such as greater amounts of faulting and tilting in the pre-Miocene units, further complicates the hydrologic properties of the basins.

\section{Acknowledgments}

We would like to thank Don Sweetkind for providing valuable geologic insights and along with Ed du Bray for providing a volcanic thickness layer used in the three-dimensional model. We would also like to thank Don Sweetkind, Dan Scheirer, Ed Mankinen, and Bob Morin for their valuable comments and suggestions, which greatly improved the manuscript. Finally, we would like to acknowledge Ted McKee, Allegra Hosford, Jeremy Lui, Carter Roberts, and Bryce Johnson for their efforts in the field.

\section{References Cited}

Alam, A.H.M. Shah, 1990, Crustal extension in the southern Snake Range and vicinity, NevadaUtah: An integrated geological and geophysical study: Baton Rouge, Louisiana State University, unpubl. $\mathrm{PhD}$ thesis, $126 \mathrm{p}$.

Alam, A.H.M. Shah and Pilger, R.H., 1991, An integrated geologic and geophysical study of the structure and stratigraphy of the Cenozoic extensional Hamlin Valley, Nevada-Utah: Geology and ore deposits of the Great Basin, symposium proceedings.

Baranov, V., 1957, A new method for interpretation of aeromagnetic maps: pseudo-gravimetric anomalies: Geophysics, v. 22, p. 359-383.

Bankey, V., Grauch, V.J.S., and Kucks, R.P., 1998, Utah aeromagnetic and gravity maps and data: a website for distribution of data: U.S. Geological Survey Open File Report 98-761, available at URL http://pubs.usgs.gov/of/1998/ofr-98-0761/utah.html.

Baranov, V. and Naudy, H., 1964, Numerical calculation of the formula of reduction to the magnetic pole: Geophysics, v. 29, p. 67-79.

Bartley, J.M., and Wernicke, B.P., 1984, The snake range decollement interpreted as a major extensional shear zone: Tectonics, v. 3, no. 6, p. 647-657.

Best, M.G., Armstrong, R.L., Graustein, W.C., Embree, G.F., and Ahlborn, R.C., 1974, Mica granites of the Kern Mountains Pluton, Eastern White Pine County, Nevada--Remobilized basement of the Cordilleran Miogeosyncline?: Geological Society of America Bulletin, v. 85, no. 8, p. 1,277-1,286. 
Best, M.G., Christiansen, E.H., and Blank, H.R., Jr., 1989, Oligocene calc-alkaline rocks of the Indian Peak volcanic field, Nevada and Utah: Geological Society of America Bulletin, v. 101, no. 8, p. 1076-1090.

Best, M.G., Christiansen, E.H., Deino, A.L., Gromme, C.S., McKee, E.H., and Noble, D.C., 1989a, Excursion 3A--Eocene through Miocene volcanism in the Great Basin of the western United States, in Chapin, C.E., and Zidek, J., eds., Field excursions to volcanic terranes in the Western United States, volume II, Cascades and Intermountain West, New Mexico Bureau of Mines and Mineral Resources Memoir 47, p. 91-133.

Best, M.G., Hintze, L.F., and Homes, R.D., 1987, Geologic map of the southern Mountain Home and northern Indian Peak Ranges (central Needle Range), Beaver County, Utah: U.S. Geological Survey Miscellaneous Investigations Series Map I-1796, scale 1:50,000.

Best, M.G., Toth, M.I., Kowallis, J.B., Willis, J.B., and Best, V.C., 1989b, Geologic map of the northern White Rock Mountains-Hamlin Valley area, Beaver County, Utah, and Lincoln County, Nevada: U.S. Geological Survey Miscellaneous Investigations Series Map I-1881, scale 1:50,000.

Blakely, R.J., 1988, Curie temperature isotherm analysis and tectonic implications of aeromagnetic data from Nevada: Journal of Geophysical Research, v. 93, no. B10, p. 11,81711,832 .

Blakely, R.J., 1995, Potential Theory in Gravity and Magnetic Applications, Cambridge University Press, New York, 441 p.

Blakely, R.J., and Jachens, R.C., 1991, Regional study of mineral resources in Nevada: Insights from 3D analysis of gravity and magnetic anomalies: Geological Society of America Bulletin, v. 103, p. 795-803.

Blakely, R.J., and Simpson, R.W., 1986, Approximating edges of source bodies from gravity or magnetic data: Geophysics, v. 51, p. 1494-1498.

Chapin, C.E., and Cather, S.M., 1994, Tectonic setting of the axial basins of the northern and central Rio Grande rift, in Keller, G.R., and Cather, S.M., eds., Basins of the Rio Grande Rift-Structure, stratigraphy, and tectonic setting: Geological Society of America Special Paper 291, p. 5-25.

Dechert, C.P., 1967, Bedrock geology of the northern Schell Creek Range, White Pine County, Nevada: Seattle, Washington, University of Washington, 266 p.

Dohrenwend, J.C., Schell, B.A., Menges, C.M., Moring, B.C., and McKittrick, M.A., 1996, Reconnaissance photogeologic map of young (Quaternary and late Tertiary) faults in Nevada, in Singer, D.A., ed., An analysis of Nevada's metal-bearing mineral resources: Nevada Bureau of Mines and Geology Open-file Report 96-2, p. 9-1--9-12.

Drewes, H., 1967, Geology of the Connors Pass Quadrangle, Schell Creek Range, east-central Nevada, U.S. Geological Survey Professional Paper 557, p. 93.

Ekren, E.B., Bucknam, R.C., Carr, W.J., Dixon, G.L., and Quinlivan, W.D., 1976, East-trending structural lineaments in central Nevada: U.S. Geological Survey Professional Paper 986, 16 p.

Gans, P.B., Mahood, G.A., and Schermer, E., 1989, Synextensional magmatism in the Basin and Range province; a case study from the eastern Great Basin, Geological Society of America Special Paper 233, 53 p.

Gans, P.B., and Miller, E.L., 1983, Style of mid-Tertiary extension in east-central Nevada, in Guidebook Part I, Geological Society of America Rocky Mountain and Cordilleran Sections Meeting: Utah Geological and Mining Survey Special Studies, v. 59, p. 107-160. 
Gans, P.B., Miller, E.L., McCarthy, J., and Ouldcott, M.L., 1985, Tertiary extensional faulting and evolving ductile-brittle transition zones in the northern Snake Range and vicinity: New insights from seismic data: Geology, v. 13, no. 3, p. 189-193.

Gans, P.B., and Seedorff, E., 2000, Cenozoic tectono-magmatic evolution of White Pine County, Nevada: Core complexes, Eocene-Oligocene volcanic centers, episodic extension and shortening, and disseminated gold deposits: Geological Society of Nevada, Symposium 2000 Field Trip Guidebook 11, p. 166.

Grauch,V.J.S., 1996, Magnetically interpreted, granitoid plutonic bodies in Nevada, 1996, in D.A. Singer, ed., An analysis of Nevada's metal-bearing mineral resources: Nevada Bureau of Mines and Geology Open-File Report 96-2, Reno, Nevada, p. 7-1 - 7-16, 1 pl.

Grauch, V.J.S., Blakely, R.J., Blank, H.R., Oliver, H.W., Plouff, Donald, and Ponce, D.A., 1988, Geophysical delineation of granitic plutons in Nevada: U.S. Geological Survey Open File Report 88-11, 7 p., 2 plates, scale 1:1,000,000.

Grauch, V.J.S., and Cordell, Lindrith, 1987, Limitations of determining density or magnetic boundaries from the horizontal gradient of gravity or pseudogravity data: Geophysics, v. 52, p. 118-121.

Hagstrum, J.T., and Gans, P.B., 1989, Paleomagnetism of the Oligocene Kalamazoo Tuff: implications for middle Tertiary extension in east central Nevada: Journal of Geophysical Research, v. 94, no. B2, p. 1827-1842.

Hauser, E., Potter, C., Hauge, T., Burgess, S. Burtch, S., Mutschler, J., Allmendinger, R., Brown, L., Kaufman, S., Oliver, J., 1987, Crustal structure of eastern Nevada from COCORP deep seismic reflection data: Geological Society of America Bulletin v. 99, p. 833-844.

Hess, R.H., 2004, Nevada Oil and Gas Well Database (NVOILWEL), Nevada Bureau of Mines and Geology Open-File Report 04-1, p. 287.

Hildenbrand, T.G., and Kucks, R.P., 1988, Total intensity magnetic anomaly map of Nevada:

Nevada Bureau of Mines and Geology Map 93A, scale 1:750,000.

Hintze, L.F., Willis, G.C., Laes, D.Y.M., Sprinkel, D.A., and Brown, K.D., 2000, Digital

Geologic Map of Utah: Utah Geological Survey Map 179DM, CD-ROM, scale 1:500,000.

Horton, B.K., and Schmitt, J.G., 1996, Sedimentology of a lacustrine fan-delta system, Miocene Horse Camp Formation, Nevada, USA: Sedimentology, v. 43, p. 133-155.

Howard, E.L., 1987, Geologic Map of the Eastern Great Basin, Nevada and Utah, Nevada Petroleum Society, scale 1:250,000, 2 sheets.

Hose, R.K., 1966, Devonian stratigraphy of the Confusion Range, west-central Utah in Geological Survey Research, 1966: U.S. Geological Survey Professional Paper 550-B, p. B36B41.

Hose, R.K., 1977, Structural geology of the Confusion Range, west-central Utah: U.S. Geolgical Survey Professional Paper 971, 9 p.

Hose, R.K., Blake, M.C., Jr., and Smith, R.M., 1976, Geology and mineral resources of White Pine County, Nevada: Nevada Bureau of Mines and Geology Bulletin 85, 105 p.

Jachens, R.C. and Moring, B.C., 1990, Maps of the thickness of Cenozoic deposits and the isostatic residual gravity over basement for Nevada: U.S. Geological Survey Open-File Report 90-404, 15 p.

Jachens, R.C., and Roberts, C.W., 1981, Documentation of a FORTRAN program, 'isocomp', for computing isostatic residual gravity: U.S. Geological Survey Open-File Report 81-574, 26 p.

Kellogg, H.E., 1964, Cenozoic stratigraphy and structure of the southern Egan Range, Nevada: Geological Society of America Bulletin, v. 75, no. 10, p. 949-968. 
Langel, R.A., 1992, International geomagnetic reference field: the sixth generation: Journal of Geomagnetism and Geoelectricity, v. 44, no. 9, p. 679-707.

Langenheim, V.E., 2005, Insights into geometry and evolution of extensional basins in the Western U.S. from comparison of geologically- and geophysically-defined locations of basinbounding faults: Geological Society of America, Abstracts with Programs, v. 37, no. 7, p. 495, Salt lake City, Utah.

Lee, D.E., Kistler, R.W., Friedman, I., and Van Loenen, R.E., 1981, Two-mica granites of northeastern Nevada: Journal of Geophysical Research, v. 86, p. 10,607-10,616.

Loucks, M.D., Tingey, D.G., Best, M.G., Christiansen, E.H., and Hintze, L.F., 1989, Geologic map of the Fortification Range, Lincoln and White Pine Counties, Nevada: U.S. Geological Survey Miscellaneous Investigations Series Map I-1866, scale 1:50,000.

Ludington, S., Cox, D.P., Leonard, K.W., and Moring, B.C., 1996, Cenozoic volcanic geology of Nevada, in Singer, D.A., ed., An analysis of Nevada's metal-bearing mineral resources:

Nevada Bureau of Mines and Geology Open-File Report 96-2, p. 5-1-5-10.

Lund, K., Beard, L.S., and Perry, W.J., Jr., 1993, Relation between extensional geometry of the northern Grant Range and oil occurrences in Railroad Valley, east-central Nevada: American Association of Petroleum Geologists Bulletin, v. 77, p. 945-962.

Mankinen, E.A., Roberts, C.W., McKee, E.H., Chuchel, B.A., and Moring, B.C., 2006, Geophysical data from the Spring and Snake valleys area, Nevada and Utah: U.S. Geological Survey Open-file Report 2006-1160, 39 p, available at URL http://pubs.usgs.gov/of/2006/1160/.

Martinez, C.M., 1999, Tertiary sedimentation in the Sacramento Pass Basin, east-central Nevada; implications for the evolution of extensional detachment faults in the Basin and Range [abs.]: American Association of Petroleum Geologists Bulletin, v. 83, p. 1891.

McGrew, A.J., 1993, The origin and evolution of the southern Snake Range decollement, east central Nevada: Tectonics, v. 12, no. 1, p. 21-34.

Miller, E.L., Dumitru, T.A., Brown, R.W., and Gans, P.B., 1999, Rapid Miocene slip on the Snake Range-Deep Creek Range fault system, east-central Nevada: Geological Society of America Bulletin, v. 111, p. 886-905.

Miller, E.L., Gans, P.B., and Garing, J., 1983, The Snake Range decollement: An exhumed midTertiary ductile-brittle transition: Tectonics, v.2, p. 239-263.

Nelson, R.B., 1966, Structural development of northernmost Snake Range, Kern Mountains, and Deep Creek Range, Nevada and Utah: American Association of Petroleum Geologists Bulletin, v. 50, p. 921-951.

Pekarek, A.H., 1988, Structural geology and petroleum potential of Long Valley, White Pine County, Nevada: Mountain Geologist, v. 25, no. 4, p. 171-180.

Perkins, M.E., Brown, F.H., Nash, W.P., McIntosh, W., and Williams, S.K., 1998, Sequence, age, and source of silicic fallout tuffs in middle to late Miocene basins of the northern Basin and Range province: Geological Society of America Bulletin, v. 110, p. 344-360.

Phelps, G.A., Roberts, C.W., and Moring, B.C., 2006, Preliminary gravity inversion model of basins east of Yucca Flat, Nevada Test Site, Nevada: U.S. Geological Survey Open-File Report 2006-1313, 21 p.

Phoenix, D.A., 1948, Geology and ground water in the Meadow Valley Wash drainage area, Nevada, above the vicinity of Caliente, State of Nevada, Office of the State Engineer, Water Resources Bulletin No. 7, p. 117. 
Plume, R.W., 1996, Hydrogeologic framework of the Great Basin region of Nevada, Utah, and adjacent states: U.S. Geological Survey Professional Paper 1409-B, 64 p., 5 plates.

Ponce, D.A., 1991, Gravity and magnetic anomalies in the Ely quadrangle, Nevada, and anomalies related to granitic plutons: Geology and Ore Deposits of the Great Basin, Reno/Sparks, Nev., Geological Society of Nevada, Proceedings, p. 103-106.

Ponce, D.A., 1997, Gravity data of Nevada: U.S. Geological Survey Digital Data Series DDS-42, 27 p., CD-ROM.

Ponce, D.A., and Glen, J.M.G, 2002, Relationship of epithermal gold deposits to large-scale fractures in northern Nevada: Economic Geology, v. 97, no. 1, p. 3-9.

Ponce, D.A., and Glen, J.M.G., 2005, A prominent basement feature in north-central Nevada and its tectonic implications: Geological Society of America, Abstracts with Programs, v. 37, no. 7 , p. 378, Salt lake City, Utah.

Ponce, D.A., Glen, J.M.G., Tilden, J.E., 2006, Geophysical investigation of the Smoke Creek Desert and their geologic implications, northwest Nevada and northeast California: U.S. Geological Survey Open-File Report 2006-1176, 25 p.

Potter, C.J., Dubiel, R.F., Snee, L.W., and Good, S.C., 1995, Eocene extension of early Eocene lacustrine strata in a complexly deformed Sevier-Laramide hinterland, northwest Utah and northeast Nevada: Geology, v. 23, p. 181-184.

Potter, C.J.; Grow, J.A.; Lund, K.; Perry, W.J.Jr.; Miller, J.J.; and Lee, M.W., 1991, Comparison of basin geometry and faulting style along a regional seismic-reflection profile from Railroad Valley to Lake Valley, Nevada: in Flanigan, D.M.H.; Hansen, M: and Flanigan, T.E., eds., Geology of White River Valley, the Grant Range, eastern Railroad Valley and western Egan Range, Nevada: Nevada Petroleum Society 1991 Fieldtrip Guidebook, p. 59.

Raines, G.L., Connors, K.A., Moyer, L.A., and Miller, R.J., 2003, Spatial Digital Database for the Geologic Map of Nevada, U.S. Geological Survey Open-File Report 03-66, Digital database, version 3.0.

Reheis, M., 1999, Extent of Pleistocene lakes in the western Great Basin: U.S. Geological Survey Miscellaneous Field Studies Map MF-2323, scale 1:800,000.

Rodgers, D.W., 1987, Thermal and structural evolution of the Deep Creek Range, west central Utah and east central Nevada: Stanford, Stanford University, Ph.D. dissertation, 149 p.

Rosendahl, B.R., 1987, Architecture of continental rifts with special reference to East Africa: Annual Review of Earth and Planetary Sciences, v. 15, p. 445-503.

Saltus, R.W., and Jachens, R.C., 1995, Gravity and basin depth maps of the Basin and Range Province, Western United States, U.S. Geological Survey Geophysical Investigations Map GP1012, scale 1:2,500,000.

Scheirer, D.S., 2005, Gravity studies of Cave, Dry Lake, and Delamar Valleys, east-central Nevada: U.S. Geological Survey Open-File Report 2005-1339, 27 p.

Simpson, R.W., Jachens, R.C., Blakely, R.J., and Saltus, R.W., 1986, A new isostatic residual gravity map of the conterminous United States with a discussion on the significance of isostatic residual gravity anomalies: Journal of Geophysical Research, v. 91, no. B8, p. 8,3488,372 .

Smith, D.L., Gans, P.B., and Miller, E.L., 1991, Palinspastic restoration of Cenozoic extension in the central and eastern Basin and Range province at latitude $39-40^{\circ} \mathrm{N}$, in Raines, G.L., Lisle, R.E., Schafer, R.W., and Wilkinson, W.H., eds., Geology and ore deposits of the Great Basin: Geological Society of Nevada Symposium Proceedings, Reno NV, p. 75-86. 
Stewart, J.H., 1980, Geology of Nevada: Nevada Bureau of Mines and Geology Special Publication 4, $136 \mathrm{p}$.

Stewart, J.H., and Carlson, J.E., 1978, Geologic map of Nevada: Nevada Bureau of Mines and Geology Map, scale 1:500,000.

Stewart, J.H., and Carlson, J.E., 1996, Selected Nevada Calderas in the BARCAS study extent: in Raines, G.L., Sawatzky, D.L., and Connors, K.A., eds., Great Basin geoscience database: U.S. Geological Survey Digital Data Series DDS-41, CD-ROM.

Strecker, U., Smithson, S.B., and Steidtmann, J.R., 1996, Cenozoic basin extension beneath Goshute Valley, Nevada, in Beratan, K.K., ed., Reconstructing the history of basin and range extension using sedimentology and stratigraphy: Geological Society of America Special Paper 303 , p. $15-26$.

Sweetkind, D.S. and du Bray, E.A., in press, Compilation of Tertiary volcanic-rock stratigraphic thicknesses and caldera structures - east-central Nevada and west-central Utah: U.S. Geological Survey Digital Data Series DS-271.

Tschanz, C.M., and Pampeyan, E.H., 1970, Geology and mineral resources of Lincoln County, Nevada: Nevada Bureau of Mines and Geology Bulletin 73, 188 p.

Wernicke, B.P., and Axen, G.J., 1988, On the role of isostacy in the evolution of normal fault systems: Geology, v. 16, no. 9, p. 848-851.

Williams, N., and Taylor, W.J., 2002, Extensional oblique-slip barrier transfer fault: The Currant Summit fault, east-central Nevada, in Ehni, W., and Faulds, J., eds., Detachment and attenuation in eastern Nevada and its application to petroleum exploration: Nevada Petroleum Society, 2002 Field Trip Guidebook, p. 149-163.

Zoback, M.L., McKee, E.H., Blakely, R.J., and Thompson, G.A., 1994, The northern Nevada rift: Regional tectono-magmatic relations and middle Miocene stress direction: Geological Society of America Bulletin, v. 106, p. 371-382. 


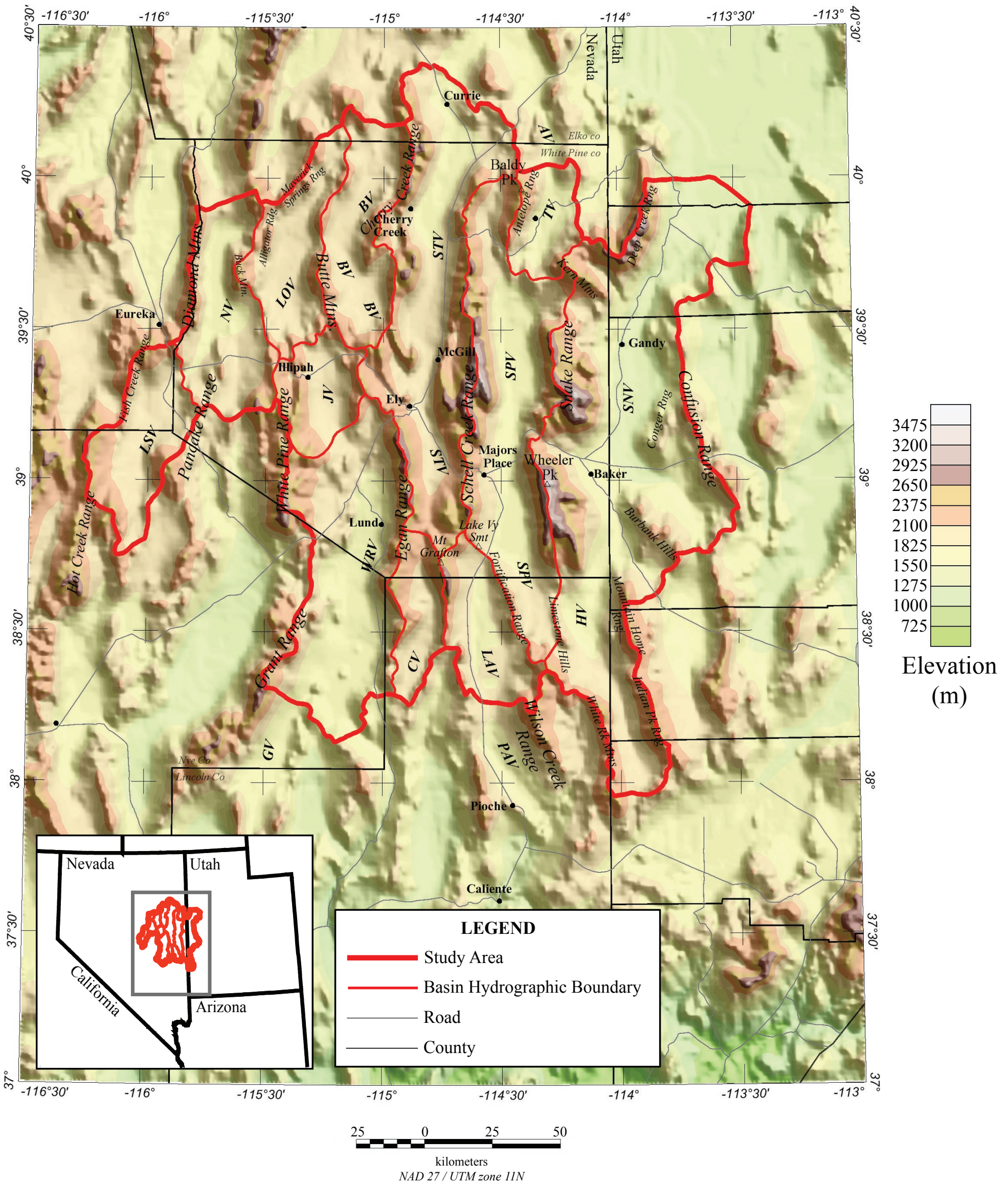

Figure 1. Shaded relief topographic index map of the study area. AV, Antelope Valley; BV, Butte Valley; CV, Cave Valley; GV, Garden Valley; HV, Hamlin Valley; JV, Jakes Valley; LAV, Lake Valley; LOV, Long Valley; LSV, Little Smokey Valley; NV, Newark Valley; PAV, Patterson Valley; SNV, Snake River Valley; SPV, Spring Valley; STV, Steptoe Valley; WRV, White River Valley. 


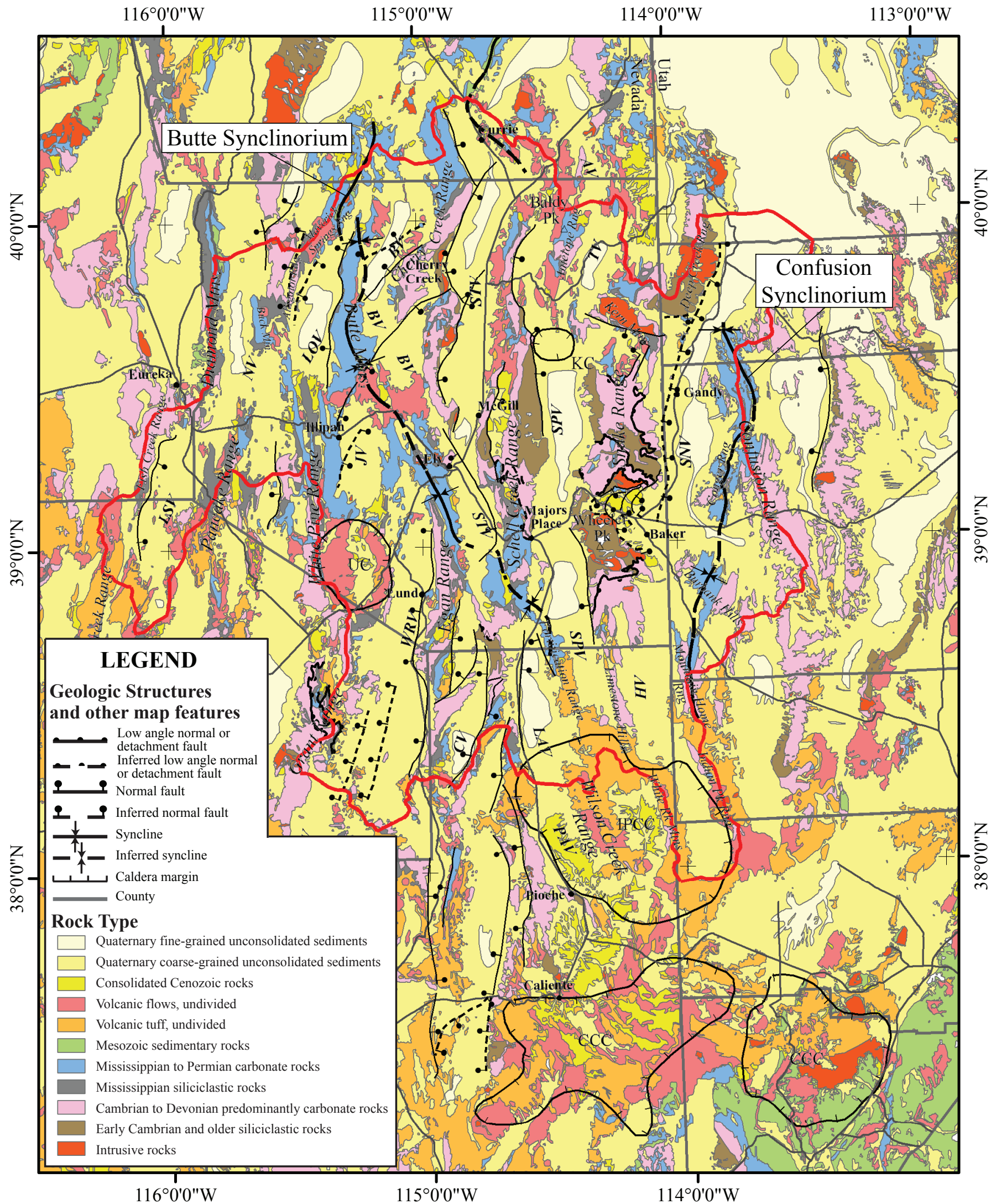

Figure 2. Simplified geologic map of the study area. Geologic descriptions of rock type (after D.

Sweetkind, written commun., 2006) and of geologic structures (modified after Dechert, 1967;

Drewes, 1967; Hose, 1977; Stewart and Carlson, 1978; Miller, Gans, and Garing, 1983; Lund, Beard, and Perry, 1993; Hintze and others, 2000; and Raines and others, 2003). Caldera margins were identified based on geologic mapping and interpretation of isostatic gravity anomalies. CCC, Caliente Caldera Complex; IPCC, Indian Peak Caldera Complex; KC, Kalamazoo Caldera; UC, Unnamed Caldera. Explanation as in figure 1. 


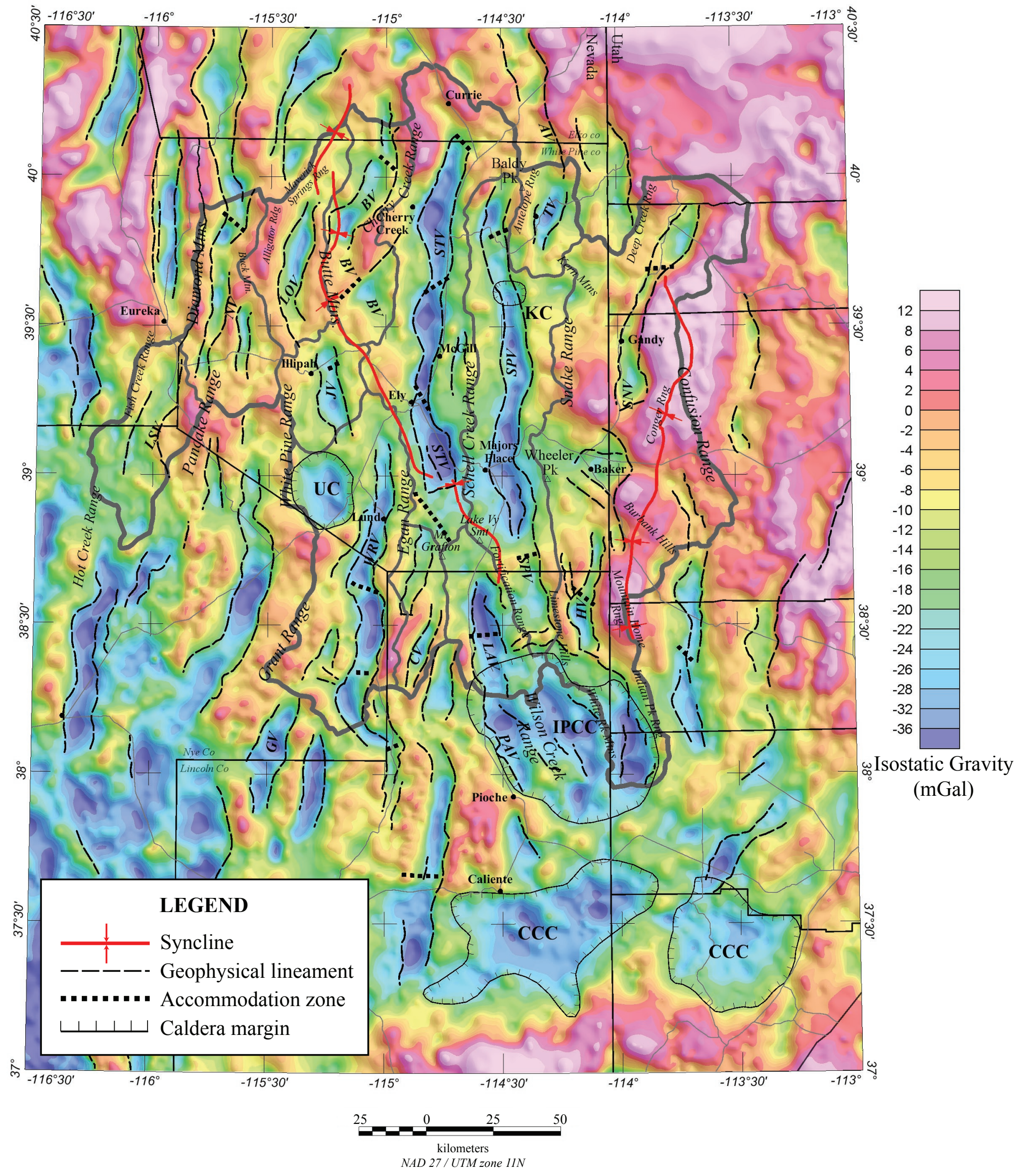

Figure 3. Isostatic gravity map of the study area showing interpreted lineaments and other geologic features. CCC, Caliente Caldera Complex; IPCC, Indian Peak Caldera Complex; KC, Kalamazoo Caldera; UC, Unnamed Caldera. Explanation as in figure 1. 


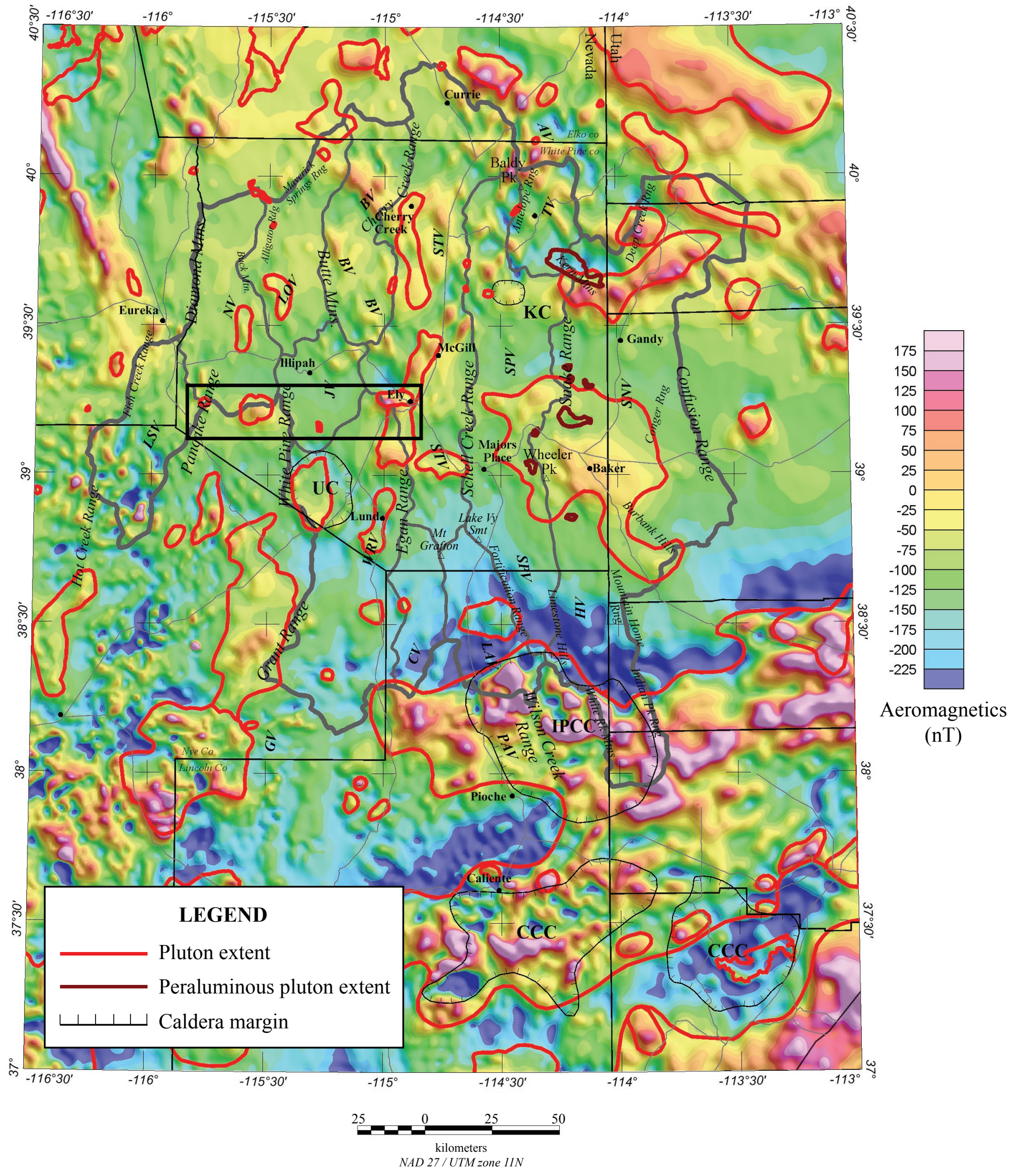

Figure 4. Aeromagnetic map of the study area showing interpreted extent of exposed and concealed plutons (modified in part from Grauch and others, 1988; Ponce, 1991; and Grauch, 1996). The black box outlines an east-west-trending corridor of Lower Cretaceous plutons that are easily identified using magnetic methods. CCC, Caliente Caldera Complex; IPCC, Indian Peak Caldera Complex; KC, Kalamazoo Caldera; UC, Unnamed Caldera. Explanation as in figure 1. 


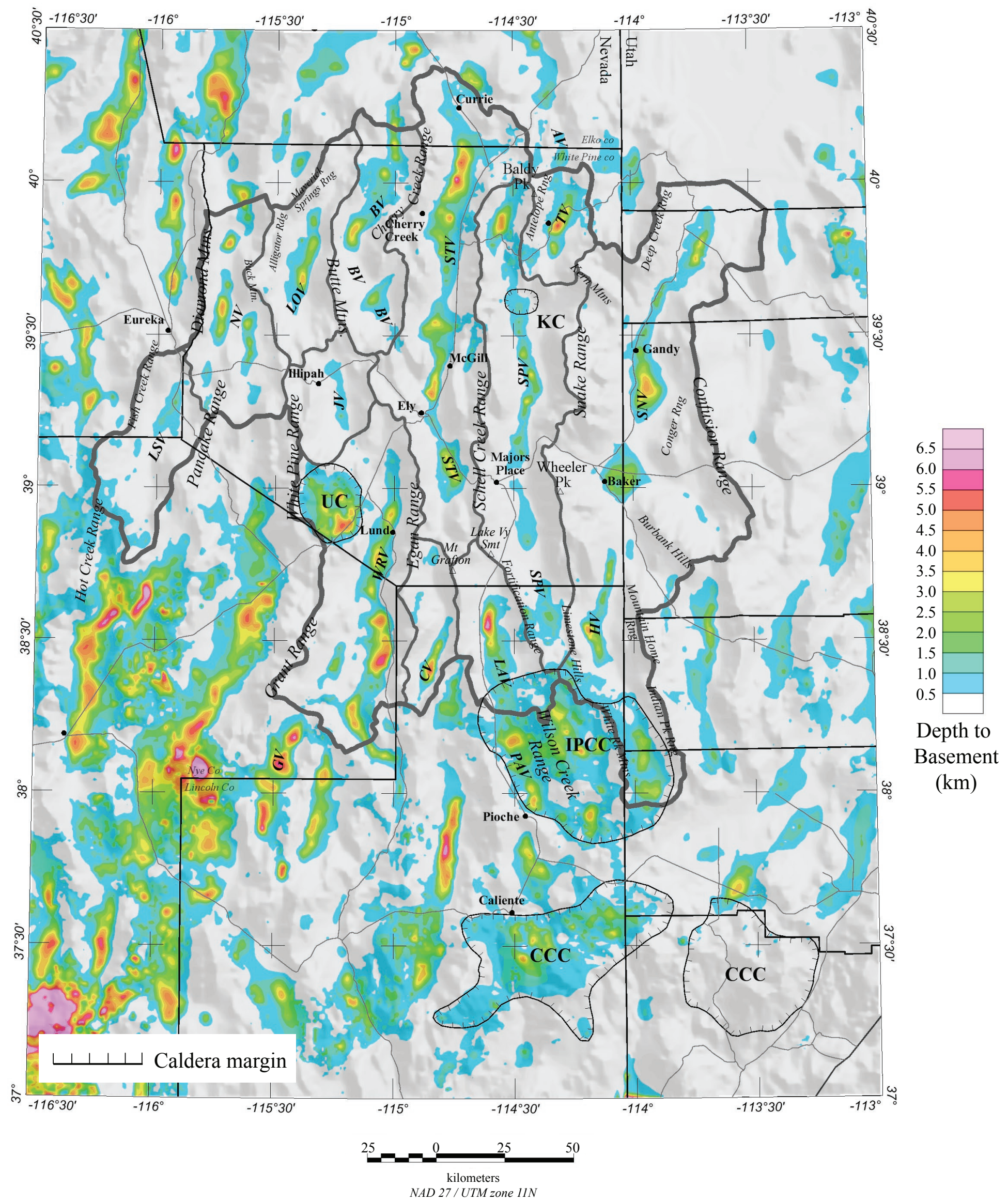

Figure 5. Depth-to-basement map of the study area draped on shaded topography. CCC, Caliente Caldera Complex; IPCC, Indian Peak Caldera Complex; KC, Kalamazoo Caldera; UC, Unnamed Caldera. Explanation as in figure 1. 

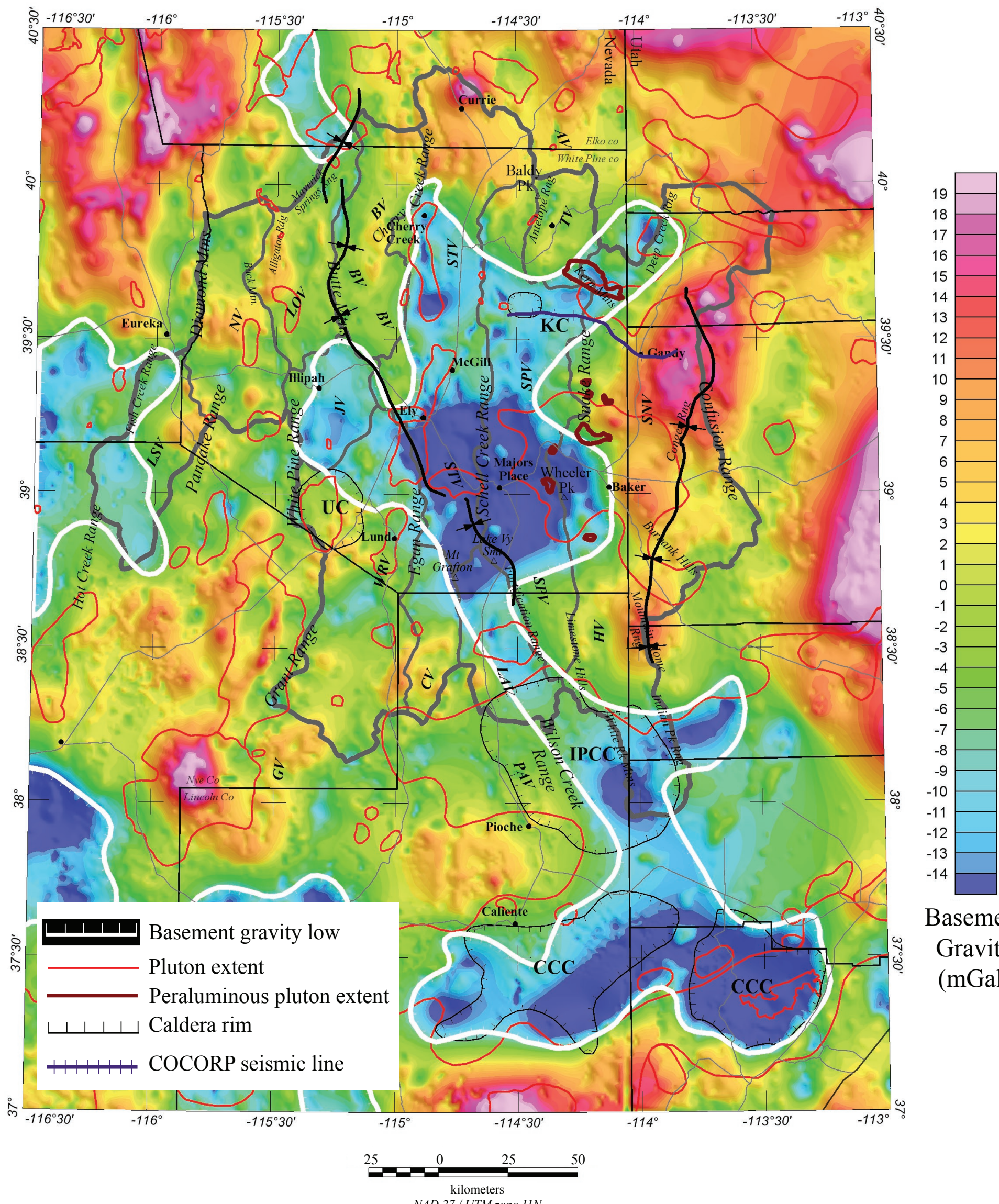

Basement

Gravity (mGal)

Figure 6 . Basement gravity map of the study area reflecting gravity anomalies within the preCenozoic basement rocks. CCC, Caliente Caldera Complex; IPCC, Indian Peak Caldera Complex; $\mathrm{KC}$, Kalamazoo Caldera; UC, Unnamed Caldera. Explanation as in figure 1. 


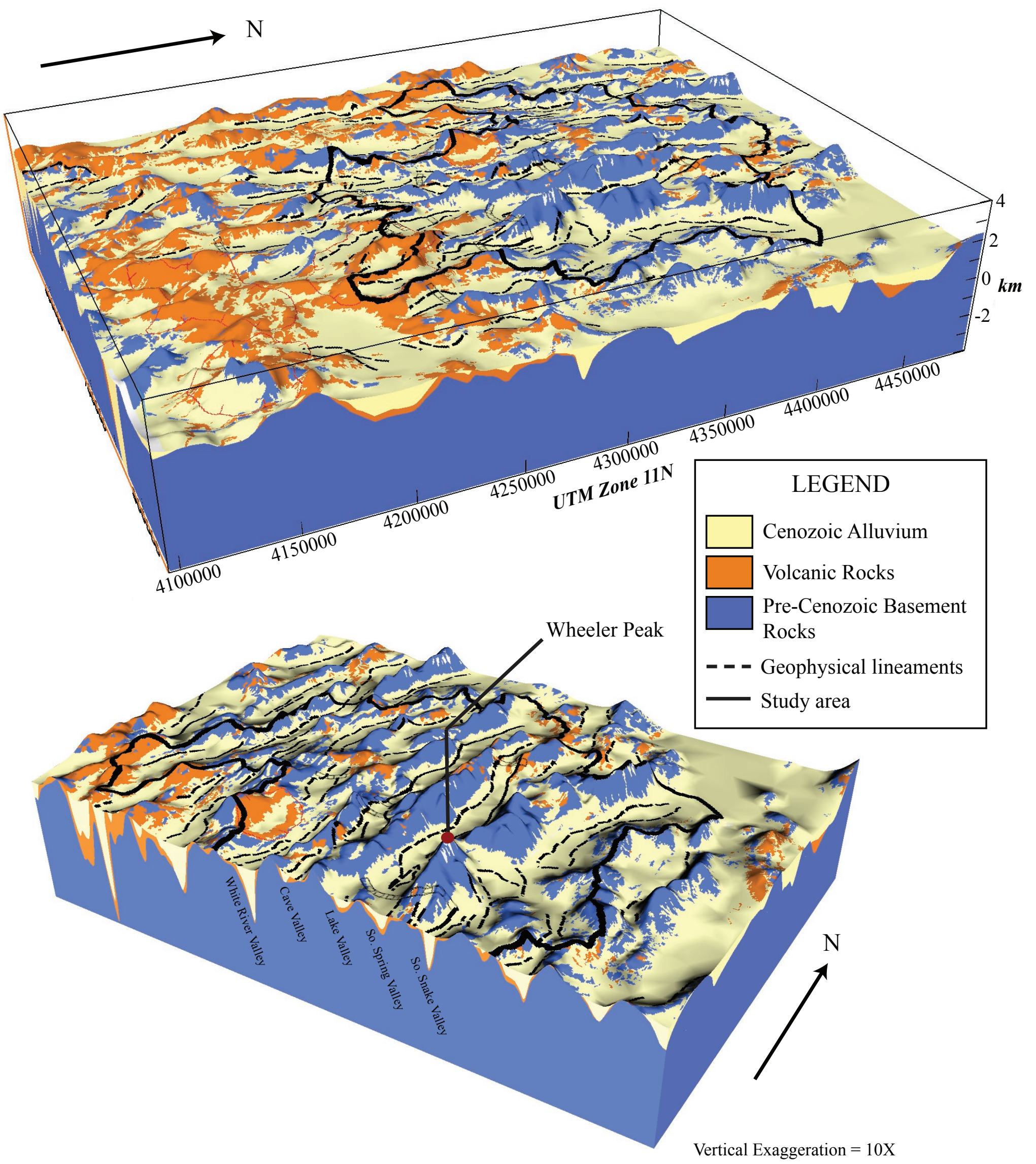

Figure 7. Simplified three-dimensional geologic model of the study area. 


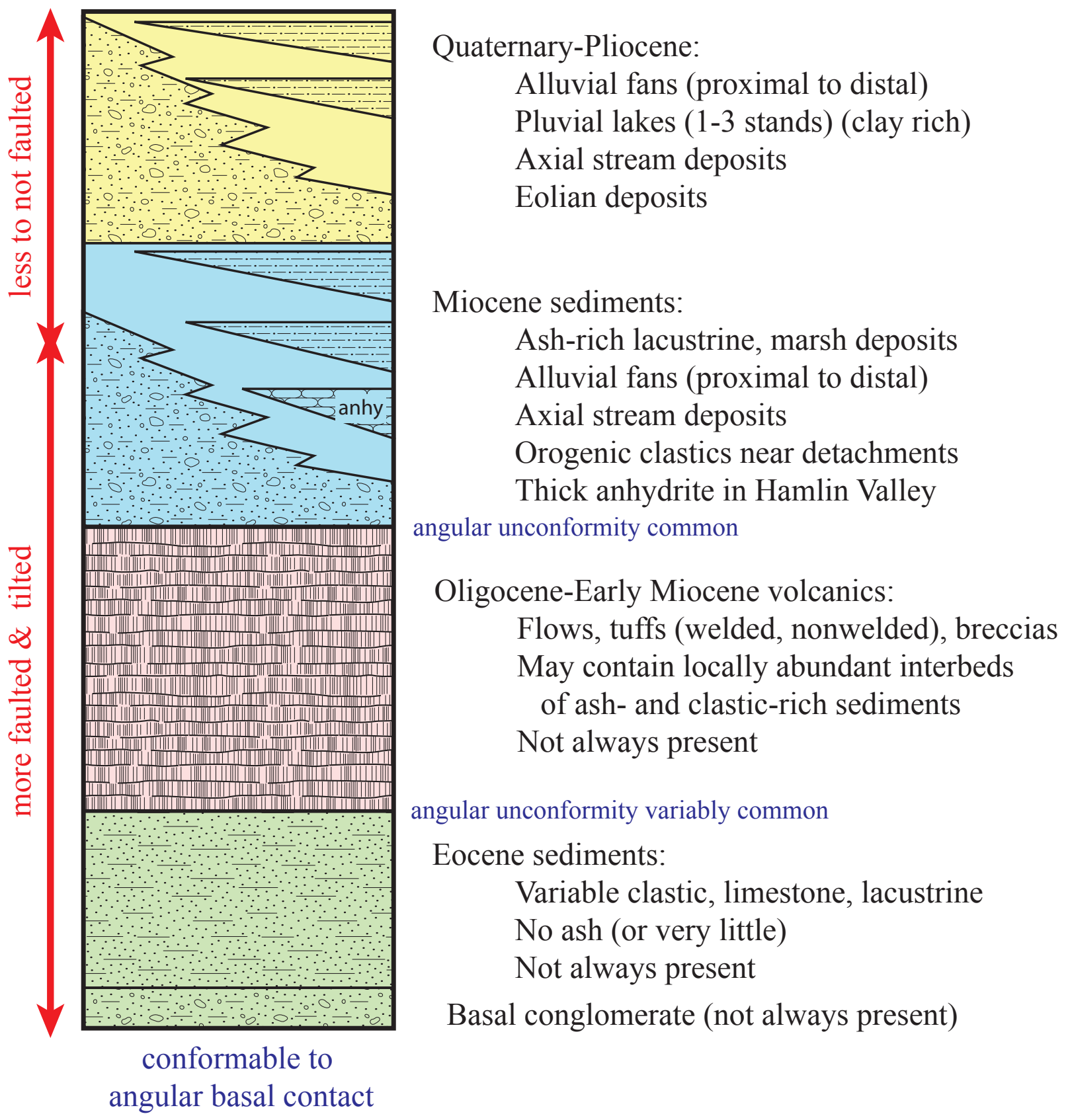

Flows, tuffs (welded, nonwelded), breccias

May contain locally abundant interbeds

of ash- and clastic-rich sediments

Not always present

angular unconformity variably common

Eocene sediments:

Variable clastic, limestone, lacustrine

No ash (or very little)

Basal conglomerate (not always present)

Figure 8. Stratigraphic column showing general basin stratigraphy for the study area. 
Plate 1. Map showing isostatic gravity anomalies and geophysically interpreted lineaments, accommodations zones, and caldera margins for east-central Nevada and west-central Utah. AV, Antelope Valley; BP, Bristol Pass; BV, Butte Valley; CCC, Caliente Caldera Complex; CV, Cave Valley; GV, Garden Valley; HV, Hamlin Valley; IPCC, Indian Peak Caldera Complex; JV, Jakes Valley; KC, Kalamazoo Caldera; KP, Kixmiller Pass; LAV, Lake Valley; LOV, Long Valley; LSV, Little Smokey Valley; NV, Newark Valley; PAV, Patterson Valley; PS, Pony Springs; RK, Rattlesnake Knoll; SACP, Sacramento Pass; SNV, Snake River Valley; SP, Shingle Pass; SPV, Spring Valley; STV, Steptoe Valley; UC, unnamed caldera; WRV, White River Valley. 
Plate 2. Map showing depth-to-basement and pre-Cenozoic consolidated rock type for eastcentral Nevada and west-central Utah. The simplified geologic units on this map were derived from the digital versions of the Nevada (Stewart and Carlson, 1978; Raines and others, 2003) and Utah (Hintze and others, 2000) state geologic maps at 1:500,000 scale. Each polygon from the source data was assigned to a hydrogeologic unit (after D. Sweetkind, written commun., 2006). The simplified geologic structures on this map were compiled from a number of sources. Regional synclines were modified after Hose (1977); detachments faults were modified after Dechert (1967); Drewes (1967); Miller, Gans, and Garing (1983), Lund, Beard, and Perry (1993); high angle normal faults were modified after Stewart and Carlson (1978), Hintze and others (2000), and Raines and others (2003). AV, Antelope Valley; BP, Bristol Pass; BV, Butte Valley; CCC, Caliente Caldera Complex; CV, Cave Valley; GV, Garden Valley; HV, Hamlin Valley; IPCC, Indian Peak Caldera Complex; JV, Jakes Valley; KC, Kalamazoo Caldera; KP, Kixmiller Pass; LAV, Lake Valley; LOV, Long Valley; LSV, Little Smokey Valley; NV, Newark Valley; PAV, Patterson Valley; PS, Pony Springs; RK, Rattlesnake Knoll; SACP, Sacramento Pass; SNV, Snake River Valley; SP, Shingle Pass; SPV, Spring Valley; STV, Steptoe Valley; UC, unnamed caldera; WRV, White River Valley. 